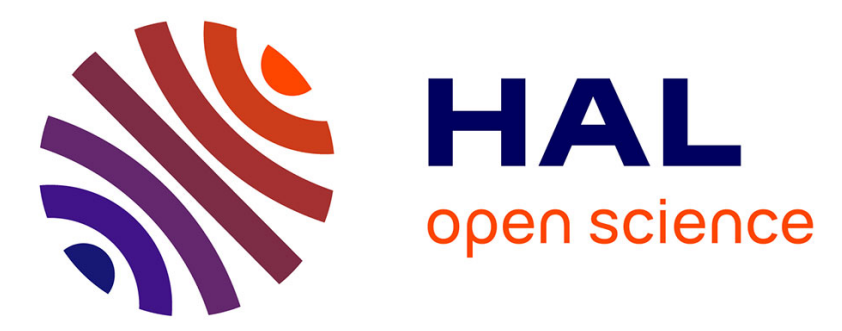

\title{
Amine-alkyl derivatives of hydantoin: New tool to combat resistant bacteria
}

Jadwiga Handzlik, Ewa Szymańska, Jacqueline Chevalier, Ewa Otrębska, Katarzyna Kieć-Kononowicz, Jean-Marie Pagès, Sandrine Alibert

\section{- To cite this version:}

Jadwiga Handzlik, Ewa Szymańska, Jacqueline Chevalier, Ewa Otrębska, Katarzyna KiećKononowicz, et al.. Amine-alkyl derivatives of hydantoin: New tool to combat resistant bacteria. European Journal of Medicinal Chemistry, 2011, 46 (12), pp.5807-5816. 10.1016/j.ejmech.2011.09.032 . hal-01425032

\section{HAL Id: hal-01425032 \\ https://hal-amu.archives-ouvertes.fr/hal-01425032}

Submitted on 16 Jan 2017

HAL is a multi-disciplinary open access archive for the deposit and dissemination of scientific research documents, whether they are published or not. The documents may come from teaching and research institutions in France or abroad, or from public or private research centers.
L'archive ouverte pluridisciplinaire HAL, est destinée au dépôt et à la diffusion de documents scientifiques de niveau recherche, publiés ou non, émanant des établissements d'enseignement et de recherche français ou étrangers, des laboratoires publics ou privés. 


\title{
Amine-alkyl derivatives of hydantoin: New tool to combat resistant bacteria
}

\author{
Jadwiga Handzlik $^{\mathrm{a}, \mathrm{c}}$, Ewa Szymańska ${ }^{\mathrm{a}}$, Jacqueline Chevalier ${ }^{\mathrm{b}}$, Ewa Otrębska ${ }^{\mathrm{a}}$, \\ Katarzyna Kieć-Kononowicz ${ }^{\mathrm{a}, \mathrm{c}}$, Jean-Marie Pagès ${ }^{\mathrm{b}, \mathrm{c}}$, Sandrine Alibert ${ }^{\mathrm{b}, \mathrm{c}, *}$ \\ ${ }^{a}$ Department of Technology and Biotechnology of Drugs, Jagiellonian University-Medical College, Medyczna 9, PL 30-688 Kraków, Poland \\ ${ }^{\mathrm{b}}$ UMR-MD-1, Transporteurs Membranaires, Chimiorésistance et Drug Design, Aix-Marseille Université/IRBA, Facultés de Médecine et de Pharmacie, \\ 27 Bd Jean Moulin, 13385 Marseille cedex 05, France \\ ${ }^{\mathrm{c}}$ COST Action BM0701 (ATENS), Brussels, Belgium
}

A R T I C L E I N F O

Article history:

Received 3 May 2011

Received in revised form

20 September 2011

Accepted 20 September 2011

Available online 1 October 2011

\section{Keywords:}

Hydantoin derivatives

Chemosensitizer

Antibiotic resistance

Efflux pumps

\begin{abstract}
A B S T R A C T
A series of new 5,5-diphenylhydantoin derivatives with various amine-alkyl terminal fragments at N1position were synthesized. Then a series of twenty-eight compounds with the same hydantoin scaffold were evaluated for their potency to combat bacterial MultiDrug Resistance (MDR). Intrinsic antibacterial activities were first evaluated. As these compounds showed no direct activity on bacteria, their influence on minimal inhibitory concentration (MIC) of nalidixic acid was tested in two strains of Enterobacter aerogenes: the reference-strain ATCC-13048 and the CM-64 strain which over-produces AcrAB-TolC efflux pump. The compounds showed moderate- or low- anti-MDR properties. According to SAR-studies, hit compounds containing 2-methoxyphenylpiperazine at N1-terminal fragment and methylcarboxyl acid one at N3-position of hydantoin have been identified for further microbiological studies and pharmacomodulations to develop efflux pump inhibitors.
\end{abstract}

(c) 2011 Elsevier Masson SAS. All rights reserved.

\section{Introduction}

Multidrug resistant (MDR) bacteria are a serious health problem due to the associated failure of the therapy of infectious diseases [1,2]. One of the most important and widespread MDR mechanism bases on bacterial efflux proteins that expel all antibiotic classes out of the cell $[3,4]$. Gram-negative bacteria provide efficient active expulsion of antibiotic molecules across the membranes and periplasm using energy-potential of membrane [3-6]. They contribute in both natural insensitivity to antibiotics and high levels of antibiotics resistance by acquiring additional mechanisms. Efflux pumps have been proposed as a potential target in order to restore the activity of antibiotics that are expelled by efflux pumps [7]. In the group of MDR Gram-negative bacteria, Enterobacter aerogenes is one of the frequently described pathogens, responsible for various hospital-acquired infections $[4,8,9]$. In the case of $E$. aerogenes such as many Enterobacteriaceae involved in infectious diseases, tripartite efflux pump AcrAB-TolC is the main efflux system which can extrude a large variety of cytotoxic substances from the cell membrane directly into the medium $[4,10,11]$. According to the recent lines of evidence, three main strategies to circumvent the bacterial resistance mechanism are described to restore an efficient intracellular concentration of antibiotics: (1) By-passing efflux activity: improving the molecular design of old antibiotics to reduce their efflux; (2) direct action on the membrane barrier: increasing the permeability of the bacterial cell envelope and drug uptake; (3) Blocking the efflux ability of bacterial cell: altering pump function [12]. Concerning the third strategy, a search for new chemical compounds with efflux pump inhibitor (EPI) properties is a current topic in medicinal chemistry. Within the search for new EPIs, some chemical groups of active compounds were identified that contain ring- or chain amine-alkyl fragments linked to various aromatic moieties. Structure analysis of some potent EPIs indicated that piperazine- (NMP, NBP, Fig. 1), primary amine-, or guanidine fragment $(\mathrm{PA} \beta \mathrm{N})$ is profitable for the activity (Fig. 1). Among others, compound PA $\beta N$, a derivative of arginine, is a wellknown efflux pump inhibitor used in various microbiological tests as a reference compound [7].

Our previous studies were focused on various chemical modifications of hydantoin to give new GPCR-agents [13-15], compounds with antiarrhythmic- and/or anticonvulsant activity [16-19] as well as antibacterial agents with some syndrome to inhibit drug resistance in mycobacterial cells [20,21]. Based on interesting structures and pharmacological properties of the 5-aromatic-hydantoin derivatives, we decided to test this chemical group for their potency to combat MDR. This work describes the

\footnotetext{
* Corresponding author. TMCD2-UMR-MD1, Laboratoire de Chimie Thérapeutique, Faculté de Pharmacie, 27 Bd Jean Moulin, 13385 Marseille cedex 05, France Tel: + 33491835 538; fax: +33 491324606 .

E-mail address: sandrine.alibert@univmed.fr (S. Alibert).
} 


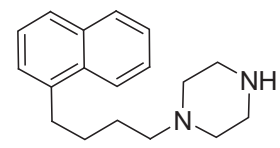

NBP

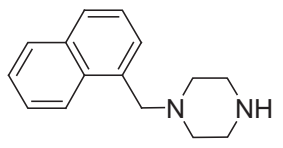

NMP

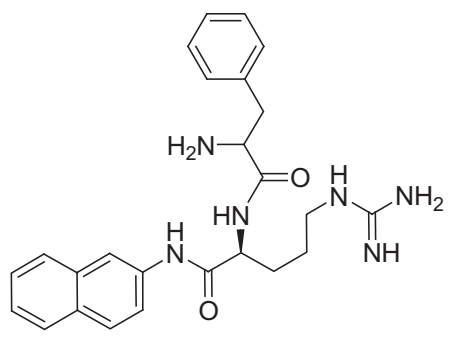

PABN

Fig. 1. Structure of some potent efflux pump inhibitors.

first step of the studies focused on 5,5-diphenylhydantoin derivatives. The research was divided into two stages. In the first stage synthesis and microbiological tests were carried out for the first generation of hydantoin derivatives 1-11 including compounds with N3-alkyl-, ester-, acid- or free hydrogen as well as tertiary amine: phenylpiperazine terminal fragment at N1-position (Table 1). According to the first results obtained, further chemical modifications of the 5,5-diphenylhydantoin derivatives 1-11 were performed by an exchange of N1-phenylpiperazine terminal fragment into primary, secondary- or tertiary amines, including heterocyclic- or non-aromatic piperazines as well as triazabicyclodecene moiety (Table 2). Syntheses of new compounds 12-28, microbiological tests using strains of E. aerogenes as well as structure-activity relationship studies were investigated.

\section{Chemistry}

Synthetic pathways to obtain the new hydantoin derivatives, belonging to first (1-11) or second generation (12-28) are illustrated on the Schemes 1-4. Synthesis of starting hydantoins 30, 31 and 33-40 from 5,5-diphenylhydantoin (29) (Scheme 1) has been performed according to described literature procedures $[13,15,16]$. Alkylation of the imidazole ring at N3-position gave methyl (30), ester (31) or trityl (40) derivatives (Scheme 1), subsequently alkylated further, this time at N1-position, which allowed to obtain the intermediate bromides (33-40) with different number of methylene groups $n=3,4,5,6$ and 8 as linkers.

Table 1

Generation I: phenylpiperazine derivatives of 5,5-diphenylhydantoin 1-11.<smiles>[R3]c1ccccc1N1CCN(CC([R])CN2C(=O)N([R])C(=O)C2(c2ccccc2)c2ccccc2)CC1</smiles>

\begin{tabular}{lllll}
\hline Cpd & $\mathrm{R}^{1}$ & $\mathrm{R}^{2}$ & $\mathrm{R}^{3}$ & $\mathrm{~m}$ \\
\hline $\mathbf{1}$ & $\mathrm{H}$ & $\mathrm{H}$ & $\mathrm{H}$ & 2 \\
$\mathbf{2}$ & $\mathrm{CH}_{3}$ & $\mathrm{H}$ & $\mathrm{H}$ & 3 \\
$\mathbf{3}$ & $\mathrm{CH}_{3}$ & $\mathrm{H}$ & $2-\mathrm{OCH}_{3}$ & 1 \\
$\mathbf{4}$ & $\mathrm{CH}_{3}$ & $\mathrm{H}$ & $\mathrm{H}$ & 1 \\
$\mathbf{5}$ & $\mathrm{CH}_{2} \mathrm{COOCH}_{3}$ & $\mathrm{H}$ & $\mathrm{H}$ & 1 \\
$\mathbf{6}$ & $\mathrm{CH}_{2} \mathrm{COOCH}_{3}$ & $\mathrm{H}$ & $\mathrm{H}$ & 2 \\
$\mathbf{7}$ & $\mathrm{CH}_{2} \mathrm{COOCH}$ & $2-\mathrm{OCH}_{3}$ & 1 \\
$\mathbf{8}$ & $\mathrm{CH}_{2} \mathrm{COOH}$ & $\mathrm{OH}$ & $2-\mathrm{OCH}_{3}$ & 1 \\
$\mathbf{9}$ & $\mathrm{CH}_{2} \mathrm{COOH}$ & $\mathrm{OH}$ & $\mathrm{H}$ & 2 \\
$\mathbf{1 0}$ & $\mathrm{CH}_{3}$ & $\mathrm{H}$ & $\mathrm{H}$ & 1 \\
$\mathbf{1 1}$ & $\mathrm{CH}_{2} \mathrm{COOCH}$ & $\mathrm{OCOCH}$ & 1 \\
\hline
\end{tabular}

The latter alkylation was performed in acetone with potassium carbonate as a base and benzyltriethylammonium chloride (TEBA) acting as a phase transfer catalyst. An excess (30-50\%) of the adequate dibromoalkane allows avoiding dimerization, a result of two-bromide substitutions. Long-term stirring (90-120 h) at room temperature gave satisfactory results. These mild conditions seem to minimize side nucleophilic substitutions that were noted during the pilot-reactions with boiling temperature. Bromides 33-40 were the starting materials for a number of nucleophilic substitution reactions that allowed preparing the target compounds (Schemes 2, 3).

A series of phenylpiperazine derivatives $(\mathbf{1}-\mathbf{3}, \mathbf{5}, \mathbf{6}, \mathbf{9})$ were prepared using synthetic pathway described in Scheme 2. Phenylpiperazine derivative $\mathbf{1}$ was synthesized within two-step process. In the first step bromoalkyl-trityl derivative of hydantoin $\mathbf{4 0}$ reacted with phenylpiperazine to give $\mathbf{4 1}$, which was next cleaved from trityl group in acidic conditions using of $90 \%$ trifluoroacetic acid (TFA) in methylene chloride to give 1. Phenylpiperazine-hydantoin derivative with N3-carboxylic terminal fragment 9 was obtained by basic hydrolysis of ester $\mathbf{4 2}$, performed in aqua-methanol conditions.

Synthesis of ethoxycarbonylpiperazine derivatives 16, 18-20 was performed as two-phase alkylation of commercial ethyl piperazine-1-carboxylate with N1-bromoalkylhydantoin derivatives 36-39 (Scheme 3). Compound 17, a 3-hydantoinacetic acid derivative, was synthesized from corresponding ester 16 by basic hydrolysis carried out in similar conditions to those used to obtain 9. In case of free-piperazine derivative 21, synthesis came up against difficulties due to presence of two amine groups in piperazine with equal sensitivity for alkylating agents. At first, a number of pilot-syntheses was performed to obtain free-piperazine derivatives by cleavage of ethoxycarbonyl group of compounds $\mathbf{1 6}$, 18-20. Deprotections in both, basic and acidic conditions, did not give the target compounds. In basic conditions, the protecting group was very stable even in case of long term heating with concentrated $\mathrm{KOH}(6 \mathrm{M})$. Similar observation was noted in case of acidic hydrolysis with various concentrations of $\mathrm{HCl}$. Acidic deprotection with TFA damaged hydantoin ring giving undesirable products. The best result gave two-phase alkylation of "free" piperazine by use of bromoalkyl derivative 39. The reaction (Scheme 3) was performed in excess of piperazine (3 eq) allowed to obtain pure compound $\mathbf{2 1}$.

Substitution of bromides 35-39 with the secondary amine 1,5,7triazabicyclo[4.4.0]dec-5-ene as well as potassium phthalimide was performed in acetone at $50-60{ }^{\circ} \mathrm{C}$, in the presence of $\mathrm{K}_{2} \mathrm{CO}_{3}$ and TBAB (Scheme 3 ). In the case of compounds 22-25, reflux conditions led after several hours to expected products of substitution with simultaneous hydrolysis of the ester group. In the case of 26-28, Gabriel method [22] for primary amines synthesis was applied. Intermediate phthalimides were treated with hydrazine monohydrate in anhydrous ethanol to give 26-28 obtained as free bases. 
Table 2

Generation II: 1-aminealkyl derivatives of 5,5-diphenylhydantoin 12-28.<smiles>[R]C(CCC)N1C(=O)N([R1])C(=O)C1(c1ccccc1)c1ccccc1</smiles>

12013

Synthesis of hydantoin derivatives with branched propyl linker $(\mathbf{4}, \mathbf{7}, \mathbf{1 0}-\mathbf{1 5})$ is shown in Scheme 4. 5,5-diphenylhydantoin alkylated at 3 position with methyl- (30) or methyl acetate (31) reacted first with 2,3-epichlorhydrine [16] to obtain the corresponding epoxide intermediates, which were cleaved by secondary amines
(Scheme 4) giving 2-hydroxypropylamine derivatives of hydantoin $(4,7,12-15,43)$. Compound 8 was obtained by basic hydrolysis of $\mathbf{4 3}$ [15]. Acylation of the hydroxyl group of compounds $\mathbf{4}$ and $\mathbf{7}$ with acetic anhydride (Scheme 4) yielded products 10b and 11b that were converted into corresponding hydrochlorides $\mathbf{1 0}$ and $\mathbf{1 1}$.<smiles>[R14]CC(C)C</smiles>

29 (DPH)<smiles>[R]N1C(=O)NC(c2ccccc2)(c2ccccc2)C1=O</smiles>

$$
\begin{aligned}
& \text { 30: } \mathbf{R}^{1}=\mathrm{CH}_{3} \\
& \text { 31: } \mathbf{R}^{1}=\mathrm{CH}_{2} \mathrm{CO}_{2} \mathrm{Me} \\
& \text { 32: } \mathbf{R}^{\mathbf{1}}=\text { Trityl }
\end{aligned}
$$<smiles>[R]N1C(=O)N([Al])C(c2ccccc2)(c2cccnc2)C1=O</smiles>

33, 34: $\mathbf{R}^{1}=\mathrm{CH}_{3} \mathbf{n}=3,5$

35-39: $\mathbf{R}^{1}=\mathrm{CH}_{2} \mathrm{CO}_{2} \mathrm{Me}, \mathbf{n}=3,4,5,6,8$

40: $\quad \mathbf{R}^{1}=$ Trityl, $\mathbf{n}=4$

Scheme 1. Synthesis of intermediates 30-40: (i) conditions described earlier [13,15,16]; (ii) dibromoalkane, $\mathrm{TEBA}^{\mathrm{K}} \mathrm{K}_{2} \mathrm{CO}_{3}$, acetone, rt. 


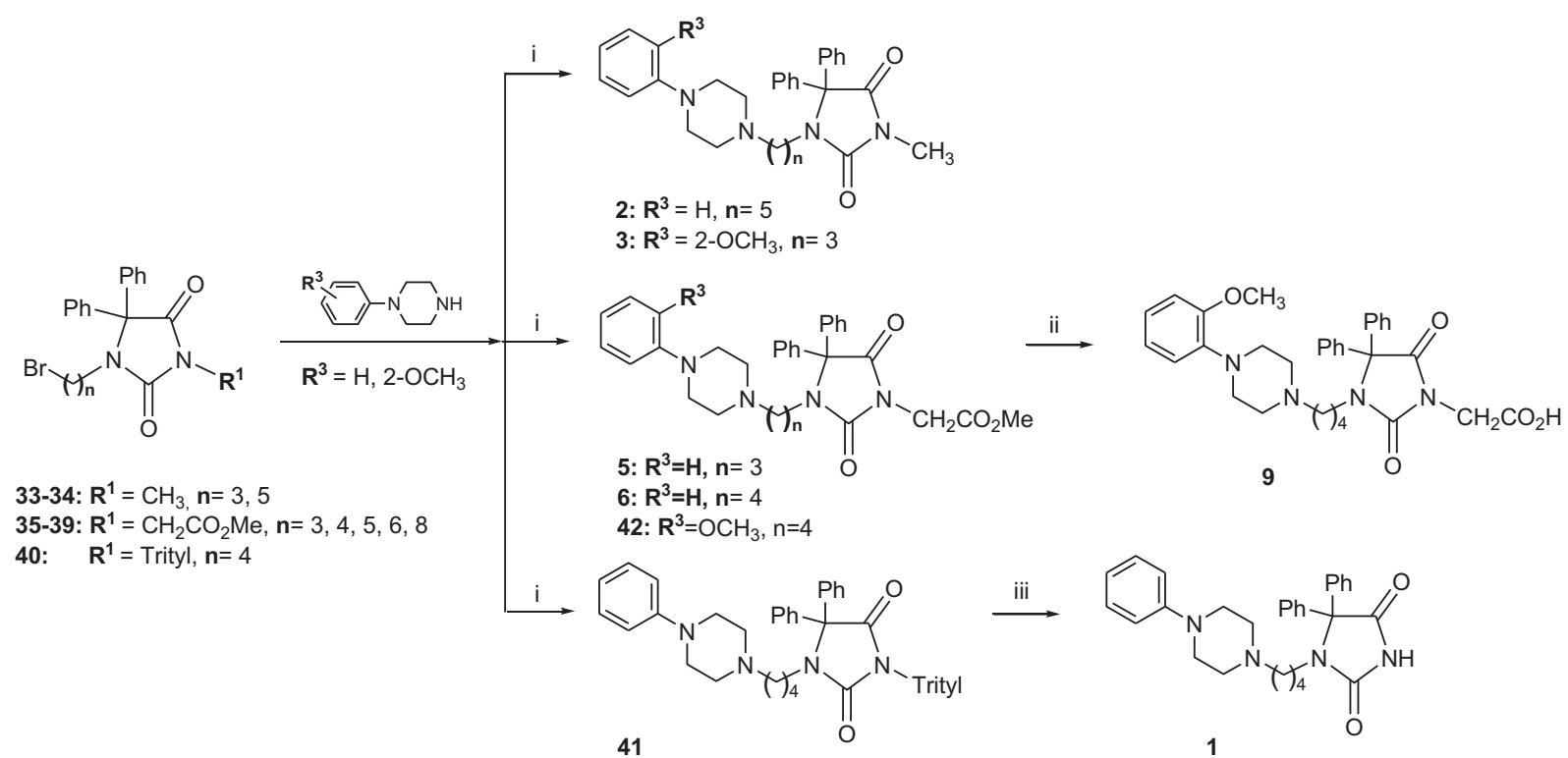

Scheme 2. (i) TEBA, $\mathrm{K}_{2} \mathrm{CO}_{3}$, acetone, $40-50{ }^{\circ} \mathrm{C}$; (ii) $\mathrm{KOH}, \mathrm{MeOH} / \mathrm{H}_{2} \mathrm{O}$; (iii) $90 \% \mathrm{TFA}, \mathrm{CH}_{2} \mathrm{Cl}_{2}$, rt.

\section{Results and discussion}

\subsection{Intrinsic anti-bacterial activity}

Compounds 1-28 were evaluated in vitro for their antibacterial activity by determining the minimum inhibitory concentration (MIC) with resistant Gram-negative bacteria E. aerogenes. Two following strains of $E$. aerogenes were used: reference-strain, ATCC 13048 and the derivative strain CM-64, which over-produces the AcrAB-TolC efflux pump. Results are shown in Table 3. Most of the tested compounds exhibited low intrinsic antibacterial activity except compound $9(0.0625 \mathrm{mM})$. However, these results show an increase

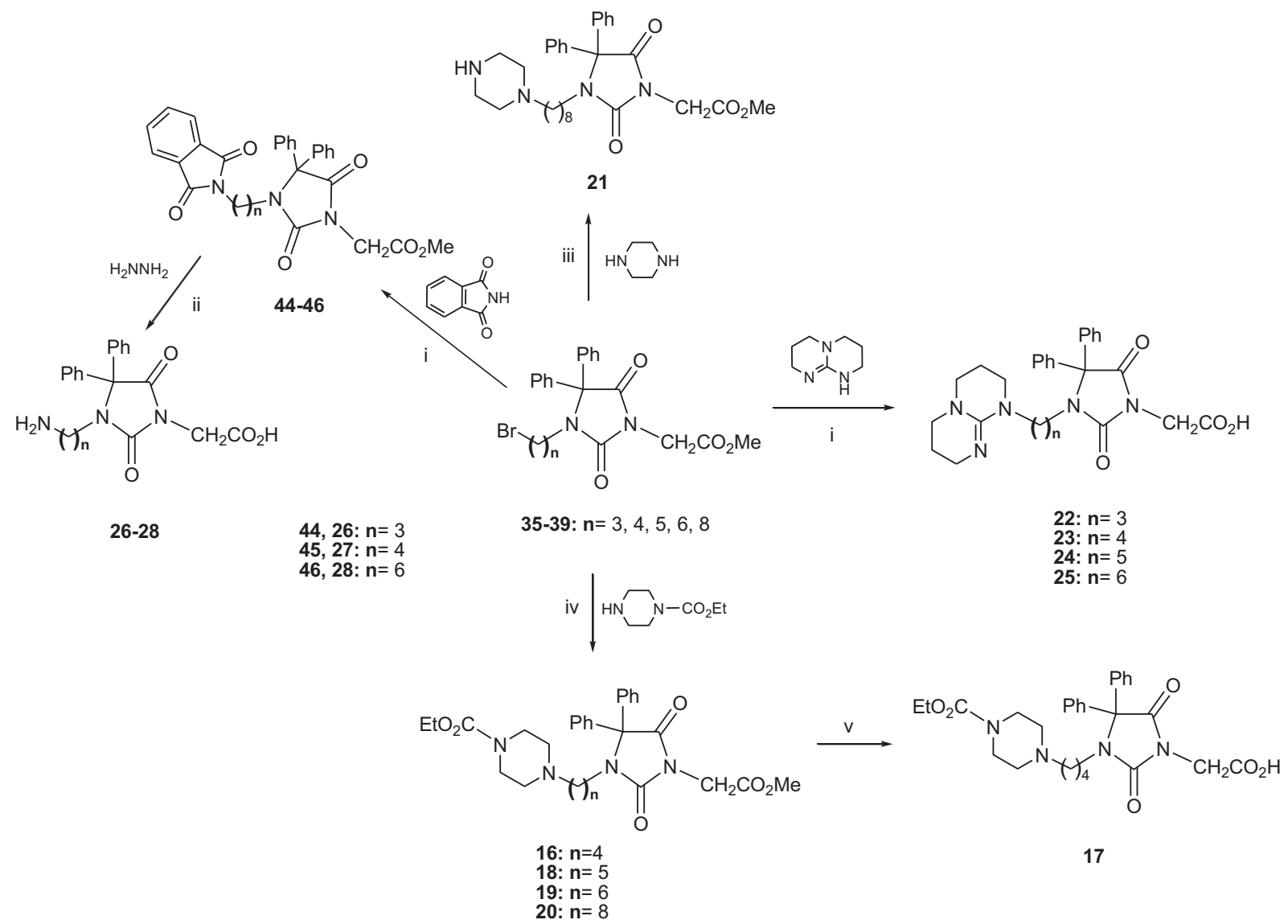

Scheme 3. (i) TBAB, $\mathrm{K}_{2} \mathrm{CO}_{3}$, acetone, $60{ }^{\circ} \mathrm{C}$; (ii) ethanol, reflux; (iii) TEBA, $\mathrm{K}_{2} \mathrm{CO}_{3}$, acetone, $40-50{ }^{\circ} \mathrm{C}$; (iv) $\mathrm{K}_{2} \mathrm{CO}_{3}$, acetone, $40-50{ }^{\circ} \mathrm{C}$; (v) $\mathrm{KOH}$, $\mathrm{MeOH} / \mathrm{H}_{2} \mathrm{O}$. 


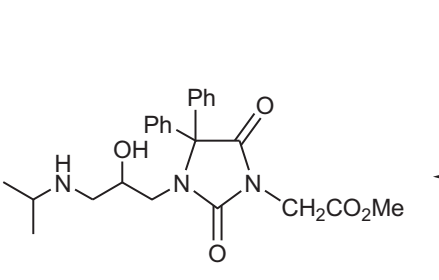

15

$$
\text { 1. } \overbrace{\mathrm{O}}^{\mathrm{Cl}}
$$

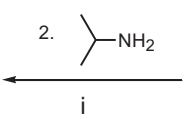

10,11

$\mathrm{HCl} \uparrow$

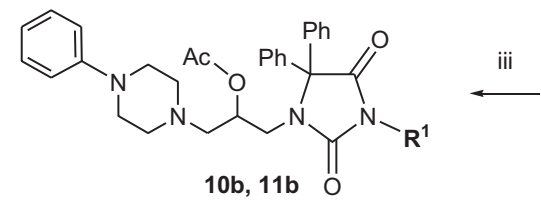

10: $\mathbf{R}^{1}=\mathrm{CH}_{3}$

11: $\mathbf{R}^{1}=\mathrm{CH}_{2} \mathrm{CO}_{2} \mathrm{Me}$<smiles>[X][C@H](Cl)CN1CCN(c2ccccc2)CC1</smiles>

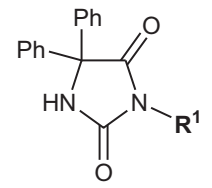

30: $\mathbf{R}^{1}=\mathrm{CH}_{3}$ 31: $\mathbf{R}^{1}=\mathrm{CH}_{2} \mathrm{CO}_{2} \mathrm{Me}$

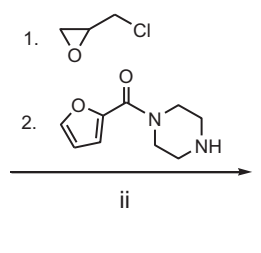

$\mid \begin{aligned} & \text { 2. } \\ & \begin{array}{l}\mathbf{R}^{3}=\mathrm{H}, \mathrm{N} \\ \mathrm{X}=\mathrm{OCH}\end{array}\end{aligned}$<smiles>CN1C(=O)N(CC(O)CN2CCN(C(=O)c3ccco3)CC2)C(c2ccccc2)(c2ccccc2)C1=O</smiles>

12

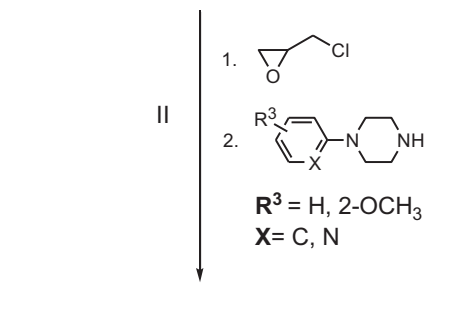<smiles>[I-]</smiles><smiles></smiles><smiles>COc1ccccc1N1CCN(CC(O)CN2C(=O)N(CC(=O)O)C(=O)C2(c2ccccc2)c2ccccc2)CC1</smiles>

8
4: $\mathbf{R}^{\mathbf{1}}=\mathrm{CH}_{3}, \mathbf{R}^{3}=\mathrm{H}, \mathbf{X}=\mathrm{C}$

7: $\mathbf{R}^{1}=\mathrm{CH}_{2} \mathrm{CO}_{2} \mathrm{Me}, \mathbf{R}^{3}=\mathrm{H}, \mathbf{X}=\mathrm{C}$

13: $\mathbf{R}^{1}=\mathrm{CH}_{3}, \mathbf{R}^{3}=\mathrm{H}, \mathbf{X}=\mathrm{N}$

14: $\mathbf{R}^{1}=\mathrm{CH}_{2} \mathrm{CO}_{2} \mathrm{Me}, \mathbf{R}^{3}=\mathrm{H}, \mathbf{X}=\mathrm{N}$

43: $\mathbf{R}^{1}=\mathrm{CH}_{2} \mathrm{CO}_{2} \mathrm{Me}, \mathbf{R}^{3}=2-\mathrm{OCH}_{3}, \mathbf{X}=\mathrm{C}$

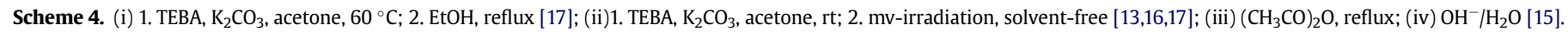

MIC for compounds 8 and $\mathbf{9}$ in CM-64 strain. This increase is probably due to the over-expressed efflux pump and therefore suggests that these compounds can be recognized and transported by AcrAB-TolC efflux pump. But the difference in activity between the two strains is less important than that of nalidixic acid. This suggests a lower affinity of hydantoin derivatives for the targeted efflux pumps.

A similar range of susceptibility values was obtained for the two strains. Most of the hydantoins had a mean value of $1.25 \mathrm{mM}$. The low intrinsic antibacterial activity of these molecules allowed us to analyze their effect on the nalidixic acid susceptibility of the MDR strain CM-64.

\subsection{Influence of hydantoins on nalidixic acid MIC}

Efflux pump inhibitory properties were also evaluated in the two strains of E. aerogenes ATCC 13048 and CM-64. To study the possible synergistic activity, the potential inhibitors were added during incubation with nalidixic acid that has been well described

Table 3

Intrinsic antibacterial activities for alkylamine derivatives of hydantoin 1-28, tested in two strains of E. aerogenes, ATCC 13048 (reference) and the derivative strain CM64 (over-producing AcrAB-TolC).

\begin{tabular}{lll}
\hline Cpd & MIC $[\mathrm{mM}]$ EA ATCC 13048 & MIC [mM] EA CM-64 \\
\hline $\mathbf{1}-\mathbf{6}$ & $>0.5$ & $>0.5$ \\
$\mathbf{7}$ & 5 & 5 \\
$\mathbf{8}$ & 0.125 & 0.25 \\
$\mathbf{9}$ & 0.0625 & 0.25 \\
$\mathbf{1 0}$ & $>0.5$ & $>0.5$ \\
$\mathbf{1 1}$ & 0.25 & 0.25 \\
$\mathbf{1 2}$ & $>1$ & $>1$ \\
$\mathbf{1 4}$ & $>5$ & $>5$ \\
$\mathbf{1 5}$ & 0.125 & 0.125 \\
$\mathbf{1 6}-\mathbf{2 8}$ & 1.25 & 1.25 \\
\hline
\end{tabular}

as efflux pump substrate [3,6,7]. PA $\beta \mathrm{N}$ (MIC $=5 \mathrm{mM}$ on ATCC 13048 and CM-64 strains) was used as a reference EPI according to previous studies [23] at the concentration of $50 \mu \mathrm{M}$. The first generation of compounds 1-11 was tested in the concentration range $62.5-333 \mu \mathrm{M}$ (Fig. 2) according to the intrinsic antibacterial activity of each compound. Compounds of second generation 12-28 were tested in the concentration corresponding to the best first generation chemosensitizers $(62.5 \mu \mathrm{M})$ to facilitate comparison. Anti-MDR activities of the compounds were expressed by activity gain A on nalidixic acid susceptibility, calculated as MIC of nalidixic acid, evaluated in absence of compound, divided by the MIC of the antibiotic in presence of the tested compound (Fig. 2).

Generally, the compounds showed moderate or weak potentiating properties, significantly lower than those obtained for strong reference efflux pump inhibitor, PA $\beta N$. The most active compounds 8 and 9 showed significant 4-fold decrease of MIC of nalidixic acid in MDR strain CM-64 and 2-fold MIC-decrease in reference-strain (ATCC 13048) at the lowest dose of $62.5 \mu \mathrm{M}$ (Fig. 2a). All compounds tested at $100 \mu \mathrm{M}(\mathbf{1}-\mathbf{6}$ and 10) had no effect on MIC of nalidixic acid in the reference-strain. In this group, compounds $\mathbf{2}$ and $\mathbf{6}$ were the most active against MDR causing 4-fold-decrease of MIC of the antibiotic in the strain, which over-expresses AcrAB-TolC (Fig. 2b). In case of compound 7, a decrease of MIC of nalidixic acid (4-fold, CM-64) was observed at higher concentration of $333 \mu \mathrm{M}$. Compounds 12-28, investigated at $62.5 \mu \mathrm{M}$, did not significantly influence MIC of nalidixic acid neither in ATCC 13048 reference-strain nor in CM-64 one.

\subsection{Structure-activity relationships}

Although the tested hydantoin derivatives did not show high chemosensitizing potency, results allowed identify some structural 
a Compounds tested at the lowest concentration $(62.5 \mu \mathrm{M})$

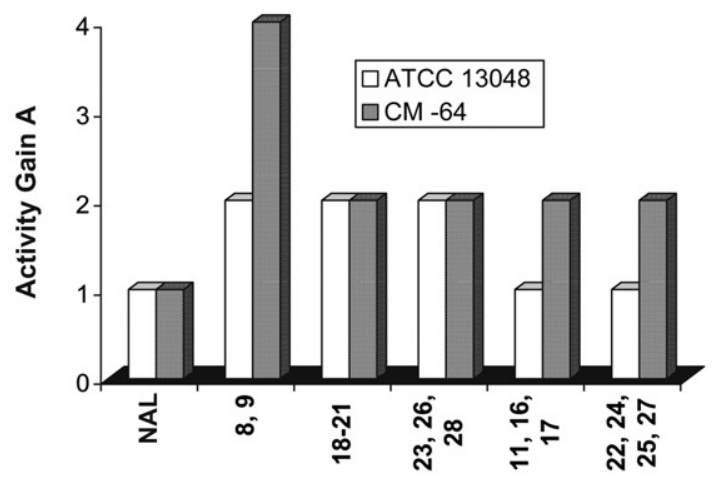

b Compounds tested at the moderate concentration $(100 \mu \mathrm{M})$

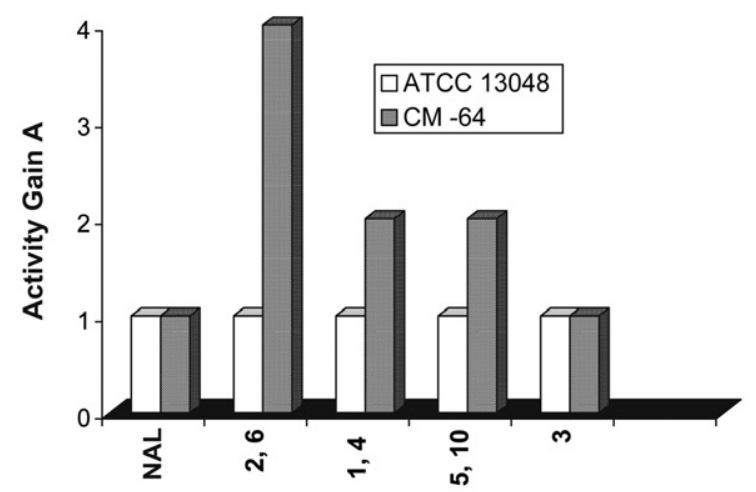

C Compounds tested at the highest concentration $(333 \mu \mathrm{M})$

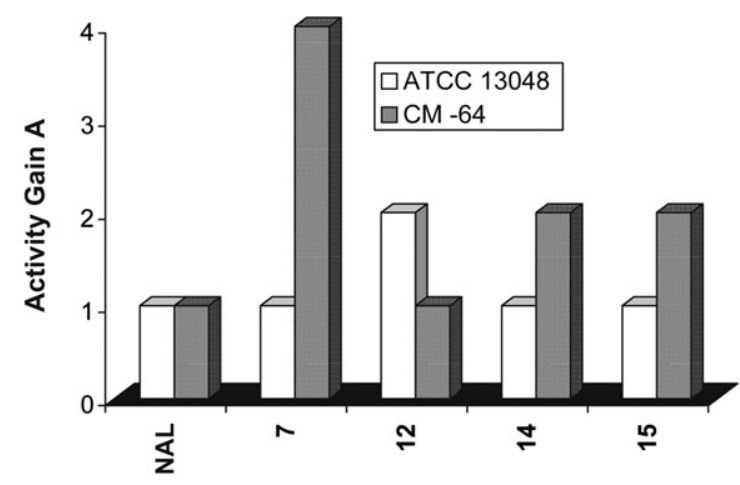

MIC of NAL at absence of a compound (1-28)

A

MIC of NAL at presence of the compound (1-28)

Fig. 2. The influence of the compounds $\mathbf{1}-\mathbf{2 8}$ on MIC of nalidixic acid tested in two strains of E. aerogenes, ATCC 13048 (reference) and CM-64 (with over-production of AcrAB-TolC). NAL- nalidixic acid; MIC-minimal inhibitory concentration; MIC of NAL in ATCC $13048=8 \mu \mathrm{g} / \mathrm{mL}$; MIC of NAL in CM-64 =128/64 $\mu \mathrm{g} / \mathrm{mL}$ Activity gains (A) for reference strong EPI, PA $\beta \mathrm{N}$, at dose of $50 \mu \mathrm{g} / \mathrm{mL}$, were as follows: 64 (ATCC 13048), 128 (CM-64).

properties profitable for the EPI activity targeted. In the first generation of hydantoin derivatives 1-11, 5,5-diphenyhydantoin as well as N1-phenylpiperazine terminated fragments are fixed structural properties for all investigated compounds. Chemical modifications were performed for substituents in N3-position and for alkyl linker between N1 and piperazine. Furthermore, modifications including electro-donor substituents at phenylpiperazine ring were investigated. The most promising compounds 8 and 9 decreased MIC of nalidixic acid in strains with over-production of
AcrAB-TolC but did not influence the MIC in reference-strains. These derivatives possess N3-carboxylic terminal fragment and 2-methoxyphenylpiperazine functional group in N1 position. They differ only within length and properties of alkyl linker between hydantoin and piperazine. As these differences are minor $(n=1$ or 2 , presence or not of hydroxyl group), it does not seem to affect activity. Other compounds with 2-methoxyphenylpiperazine fragment did not potentiate antibiotic activity in CM-64 or decrease nalidixic acid MIC at higher concentrations (Fig. 2). Comparing structures of the generation 1 compounds, the main difference is shown in case of N3-substituent. Compounds with N3-H (1) and N3-ester fragment (5-7 and 11) showed various activities. The compounds displayed chemosensitizing activity lower than that of compounds possessing carboxylic group $(\mathbf{8}, \mathbf{9})$. The best of them decreased MIC of nalidixic acid at higher doses: $100 \mu \mathrm{M}(6)$ and $333 \mu \mathrm{M}(7)$. Basing on this observation, the substituent $\mathrm{CH}_{2} \mathrm{COOH}$ at $\mathrm{N} 3$ seems to be a structural factor improving potentiating-properties. The influence of N3substituents on decrease of MIC of nalidixic acid in CM-64 is as follows: $\mathrm{CH}_{2} \mathrm{COOH}>\mathrm{CH}_{2} \mathrm{COOCH}_{3}=\mathrm{CH}_{3}>\mathrm{H}$.

Results obtained for first generation 1-11 revealed two most promising chemosensitizers (8 and $\mathbf{9}$ ), which contain methylcarboxylic acid N3-substituent, and 2-methoxyphenylpiperazine. The role of these two fragments was investigated in the next studies of the second generation of hydantoin derivatives (12-28). In this context, phenyl ring of phenylpiperazine moiety was replaced by 2-furoyl (12), 2-pyridil- $(\mathbf{1 3}, \mathbf{1 4})$, ethoxycarbonyl (16-20) or free hydrogen (21) as well as phenylpiperazine was exchanged into primary amine (26-28), isopropylamine (15) or triazabicyclodecene fragment (22-25) in order to understand the impact of the change of pharmacophore features. This new generation of compounds possesses either N3-carboxylic terminal fragment $(\mathbf{1 7}, \mathbf{2 2 - 2 8})$ or the corresponding methyl ester (14-16, 18-21) (Table 2). Results demonstrated that no compound of the second generation $(\mathbf{1 2}-\mathbf{2 8})$ had better chemosensitizing-properties than that of compounds 8 and 9 but some structure-activity relationship conclusions can be done. This second part of the study confirms the importance of the 2methoxyphenyl substituent of piperazine. Its replacement by non-aromatic functional group or an aromatic ring with a weaker electronic density as pyridyl one led to decrease of activity gain. Moreover, the nature of the amine group seems also to be important. Indeed, the replacement of piperazine by primary amine or triazabicyclodecene groups which have stronger basic properties decrease activity gain of the chemosensitizers. Higher basic properties lead to higher ionization of molecules, which could affect either the interaction with the putative target of chemosensitizers and/or the crossing through bacterial membranes.

\section{Conclusion}

The chemosensitizing activity of 28 5,5-diphenylhydantoin derivatives were evaluated in MDR bacterial cells which overproduce AcrAB-TolC efflux pump in order to investigate the possibility to use these compounds as EPIs. This study shows that this series of compounds potentiates nalidixic acid activity at rather low concentrations. Two hits and four pharmacophoric groups have been identified as substrates of efflux pumps. However, the affinity for the efflux target is not sufficiently higher to reverse totally the resistance to nalidixic acid. New chemical modifications are under consideration to improve the affinity to the target: a change in the position of pharmacophoric groups on the hydantoin scaffold is particularly investigated. 


\section{Experimental}

\subsection{Chemistry}

NMR spectra were recorded on following apparatus: a Varian Mercury VX 300 MHz PFG instrument (Varian Inc., Palo Alto, CA, USA) in [d6]-DMSO at ambient temperature using the solvent signal as an internal standard $\left(300 \mathrm{MHz}\right.$ for ${ }^{1} \mathrm{H}$ and $75 \mathrm{MHz}$ for $\left.{ }^{13} \mathrm{C}\right)$ and on a Brucker ARX $200 \mathrm{MHz}$ spectrometer with tetramethylsilane (TMS) as internal reference; chemical shifts are given on the $\delta(\mathrm{ppm})$ scale with $\mathrm{J}$ values in Hertz. Thin-layer chromatography was performed on pre-coated Merck silica gel $60 \mathrm{~F}_{254}$ aluminum sheets, the used solvent systems were: (I) toluene/acetone 40:3; (II) toluene/acetone/methanol 15:5:1; (III) toluene/acetone/methanol 5:5:1; (IV) methylene chloride/acetone 10:2, (V) methylene chloride/methanol 1:1. Melting points were determined using MelTemp II apparatus and are uncorrected. Elemental analyses were within $\pm 0.4 \%$ of the theoretical values unless stated otherwise. Syntheses and chemical characteristics for compounds $\mathbf{2}-\mathbf{8}, \mathbf{1 2}-\mathbf{1 5}$, 30-34, 42 and 43 were described earlier [13,15-17].

\subsubsection{General procedure for bromoalkyl derivatives (35-40)}

A mixture of the appropriate N3-substituted derivative of 5,5diphenylhydantoin 31 or 32 (30 mmol), TEBA (3.96 mmol, $0.9 \mathrm{~g}$ ) and potassium carbonate $(87 \mathrm{mmol}, 12 \mathrm{~g})$ in acetone $(60 \mathrm{~mL})$ was stirred under reflux for $1 \mathrm{~h}$, then an appropriate dibromoalkane (36-42 mmol, $1.2-1.4 \mathrm{eq}$ ) in acetone (30 mL) was added. The mixture was stirred at room temperature for $45-150 \mathrm{~h}$, according to a progress controlled by TLC (I). Then, inorganic precipitate was filtered off, the mother liquor was evaporated. The residue was crystallized with methanol.

5.1.1.1. 1-(4-bromobutyl)-5,5-diphenyl-3-tritylimidazolidine-2,4-dione (40). 5,5-diphenyl-3-tritylhydantoin 32 (15.1 g), 1,4-dibromopropane (36 mmol, $7.78 \mathrm{~g}$ ) were used. Reactants were stirred for $85 \mathrm{~h}$. White crystals of 40 (12.24 g, $19.3 \mathrm{mmol}, 64 \%)$ m.p. $134-135{ }^{\circ} \mathrm{C}, R_{f}(\mathrm{I}): 0.78$. Anal. Calcd. for $\mathrm{C}_{38} \mathrm{H}_{33} \mathrm{BrN}_{2} \mathrm{O}_{2} \%$ : C, 72.49; $\mathrm{H}, 5.28 ; \mathrm{N}, 4.45$. Found: $\mathrm{C}$, 72.65.; H, 5.24; N, 4.58. ${ }^{1} \mathrm{H}$ NMR (DMSO- $\left.d_{6}\right) \delta[\mathrm{ppm}]: 0.65(\mathrm{qu}$, $\left.J=7.40 \mathrm{~Hz}, 2 \mathrm{H}, \mathrm{N} 1-\mathrm{CH}_{2}-\mathrm{CH}_{2}\right), 1.27\left(\mathrm{qu}, J=7.40 \mathrm{~Hz}, 2 \mathrm{H}, \mathrm{Br}-\mathrm{CH}_{2}-\mathrm{CH}_{2}\right)$, 3.12-3.21 (m, 4H, N1- $\left.\mathrm{CH}_{2}, \mathrm{Br}-\mathrm{CH}_{2}\right), 6.93-6.96$ ( $\mathrm{m}, 4 \mathrm{H}, 2 \times \mathrm{C} 5-\mathrm{Ph}-\overline{3}, 5-$ H), 7.15-7.28 (m, 15H, 5× Ph-2,4,6-H), 7.35-7.42 (m, 6H, 3× trtPh-3,5H). ${ }^{13} \mathrm{C}$ NMR (75 MHz, DMSO-d6) $\delta$ [ppm]: 26.5, 29.8, 34.5, 41.1, 73.5, $126.9,127.9,128.3,128.4,129.3,137.4,137.5,142.7,154.9,173.8$.

5.1.1.2. Methyl 2-(3-(3-bromopropyl)-2,5-dioxo-4,4-diphenylimidazolidin-1-yl)acetate (35). Methyl 2-(2,5-dioxo-4,4-diphenylimidazolidin-1-yl)acetate 31 (9.72 g), 1,3-dibromopropane (7.87 g) were used. Reactants were stirred for $45 \mathrm{~h}$. White crystals of 35 (9.2 g, 20.66 mmol, 69\%) m.p. $126-128{ }^{\circ} \mathrm{C}, R_{f}(\mathrm{I}): 0.79$. Anal. Calcd. for $\mathrm{C}_{21} \mathrm{H}_{21} \mathrm{BrN}_{2} \mathrm{O}_{4}$ \%: C, 56.64; H,. 4.75; N, 6.29. Found: C, 56.48; H, 4.72; $\mathrm{N}, 6.41 .{ }^{1} \mathrm{H}$ NMR (DMSO- $\left.d_{6}\right) \delta[\mathrm{ppm}]:$ 1.23-1.32 (qu def., $2 \mathrm{H}$, $\left.\mathrm{Br}-\mathrm{CH}_{2} \mathrm{CH}_{2}\right), 3.15-3.19\left(\mathrm{t}, J=6.67 \mathrm{~Hz}, 2 \mathrm{H}, \mathrm{N} 1-\mathrm{CH}_{2}\right), 3.41-3.46(\mathrm{t}$ def., $\left.2 \mathrm{H}, \mathrm{Br}-\mathrm{CH}_{2}\right), 3.70\left(\mathrm{~s}, 3 \mathrm{H}, \mathrm{OCH}_{3}\right), 4.35\left(\mathrm{~s}, 2 \mathrm{H}, \mathrm{N} 3-\mathrm{CH}_{2}\right)$, 7.26-7.30 (m, 4H, 2× Ph-3,5-H), 7.42-7.47 (m, 6H, 2× Ph-2,4,6-H).

5.1.1.3. Methyl 2-(3-(4-bromobutyl)-2,5-dioxo-4,4-diphenylimidazolidin-1-yl)acetate (36). Ester 31 (9.72 g), 1,4-dibromobutane (39 mmol, $8.42 \mathrm{~g}$ ) were used. Reactants were stirred for $120 \mathrm{~h}$. White crystals of 36 ( $12.1 \mathrm{~g}, 26.34 \mathrm{mmol}, 88 \%)$ m.p. $105-106{ }^{\circ} \mathrm{C}, R_{f}$ (I):0.56. Anal. Calcd. for $\mathrm{C}_{22} \mathrm{H}_{23} \mathrm{BrN}_{2} \mathrm{O}_{4}$ \%: C, 57.53; H,. 5.05; N, 6.10 . Found: C, 57.42; H, 5.11; N, 6.01. ${ }^{1} \mathrm{H}$ NMR (DMSO- $\left.d_{6}\right) \delta[\mathrm{ppm}]$ : 0.83-0.93 (qu def., $2 \mathrm{H}, \mathrm{N} 1-\mathrm{CH}_{2}-\mathrm{CH}_{2}$ ), 1.39-1.48 (qu def., $2 \mathrm{H}$, $\left.\mathrm{Br}-\mathrm{CH}_{2}-\mathrm{CH}_{2}\right), 3.19-3.23\left(\mathrm{t}, J=6.67 \mathrm{~Hz}, 2 \mathrm{H}, \mathrm{N} 1-\mathrm{CH}_{2}\right), 3.33-3.35(\mathrm{t}$ def., $\left.2 \mathrm{H}, \overline{\mathrm{Br}}-\mathrm{CH}_{2}\right), 3.70\left(\mathrm{~s}, 3 \mathrm{H}, \mathrm{O}-\mathrm{CH}_{3}\right), 4.34\left(\mathrm{~s}, 2 \mathrm{H}, \mathrm{N} 3-\mathrm{CH}_{2}\right)$, 7.27-7.30 (m, 4H, 2× Ph-3,5-H), 7.39-7.47 (m, 6H, $2 \times$ Ph-2,4,6-H).
5.1.1.4. Methyl 2-(3-(5-bromopentyl)-2,5-dioxo-4,4-diphenylimidazolidin-1-yl)acetate (37). Ester 31 (9.72 g), 1,5-dibromopentane (39 mmol, $8.95 \mathrm{~g}$ ) were used. Reactants were stirred for $134 \mathrm{~h}$. White crystals of 37 (8.5 g, $18 \mathrm{mmol}, 59 \%)$ m.p. $114-115{ }^{\circ} \mathrm{C}, R_{f}$ (I):0.58. Anal. Calcd. for $\mathrm{C}_{23} \mathrm{H}_{25} \mathrm{BrN}_{2} \mathrm{O}_{4} \%$ : C, 58.36; H,. 5.32; N, 5.92. Found: C, 58.62; H, 5.39; N, 5.88. ${ }^{1} \mathrm{H}$ NMR (DMSO- $\left.d_{6}\right) \delta[\mathrm{ppm}]$ : 0.71-0.76 (qu def., $2 \mathrm{H}, \mathrm{Br}-\mathrm{C}_{2} \mathrm{H}_{4}-\mathrm{CH}_{2}$ ), 0.97-1.07 (qu def., $2 \mathrm{H}$, $\mathrm{N} 1-\mathrm{CH}_{2}-\mathrm{CH}_{2}$ ), $1.42-1.51$ (qu def., $2 \mathrm{H}, \mathrm{Br}-\mathrm{CH}_{2}-\mathrm{CH}_{2}$ ), $3.24-3.28$ (t, $J=6.67 \mathrm{~Hz}, 2 \mathrm{H}, \mathrm{N} 1-\mathrm{CH}_{2}$ ), 3.31 (t def., $\left.2 \mathrm{H}, \mathrm{Br}-\overline{\mathrm{CH}}_{2}\right), 3.70$ (s, $3 \mathrm{H}$, $\left.\mathrm{OCH}_{3}\right), 4.33\left(\mathrm{~s}, 2 \mathrm{H}, \mathrm{N} 3-\mathrm{CH}_{2}\right), 7.27-7.30(\mathrm{~m}, 4 \mathrm{H}, 2 \times \mathrm{Ph}-3,5-\mathrm{H})$, 7.44-7.46 (m, 6H, 2× Ph-2,4,6-H). ${ }^{13} \mathrm{C}$ NMR (75 MHz, DMSO-d6) $\delta$ [ppm]: 24.9, 26.9, 31.9, 34.9, 41.5, 41.6, 53.0, 74.9, 128.6, 129.3, $129.4,137.2,154.6,168.4,173.3$.

5.1.1.5. Methyl 2-(3-(6-bromohexyl)-2,5-dioxo-4,4-diphenylimidazolidin-1-yl)acetate (38). Ester 31 (9.72 g), 1,6-dibromohexane ( $39 \mathrm{mmol}, 9.51 \mathrm{~g}$ ) were used. Reactants were stirred for $48 \mathrm{~h}$. White crystals of 38 (8.15 g, $16.72 \mathrm{mmol}, 56 \%)$ m.p. $119-120^{\circ} \mathrm{C}, R_{f}$ (I):0.66. Anal. Calcd. for $\mathrm{C}_{24} \mathrm{H}_{27} \mathrm{BrN}_{2} \mathrm{O}_{4} \%$ : C, 59.14; H,. 5.58; N, 5.75 . Found: $\mathrm{C}, 59.25 ; \mathrm{H}, 5.61 ; \mathrm{N}, 5.70 .{ }^{1} \mathrm{H}$ NMR (DMSO- $\left.d_{6}\right) \delta$ [ppm]: 0.69-0.77 (qu def., $2 \mathrm{H}, \mathrm{N} 1-\mathrm{C}_{2} \mathrm{H}_{4}-\mathrm{CH}_{2}$ ), 0.85-0.95 (qu def., $2 \mathrm{H}$, $\mathrm{Br}-\mathrm{C}_{2} \mathrm{H}_{4}-\mathrm{CH}_{2}$ ), $1.00-1.07$ (qu def., $2 \overline{\mathrm{H}}, \mathrm{N} 1-\mathrm{CH}_{2}-\mathrm{CH}_{2}$ ), $1.46-1.55$ (qu def., $\left.2 \mathrm{H}, \mathrm{Br}-\mathrm{CH}_{2}-\mathrm{CH}_{2}\right), 3.23-3.31\left(\mathrm{~m}, 2 \mathrm{H}, \mathrm{N} 1-\mathrm{CH}_{2}\right), 3.35-3.39$ (t def., $\left.2 \mathrm{H}, \mathrm{Br}-\mathrm{CH}_{2}\right), 3.70\left(\mathrm{~s}, 3 \mathrm{H}, \mathrm{OCH}_{3}\right), 4.33\left(\mathrm{~s}, 2 \mathrm{H}, \mathrm{N} 3-\mathrm{CH}_{2}\right)$, 7.26-7.29 (m, 4H, 2× Ph-3,5-H), 7.44-7.46 (m, 6H, 2× Ph-2,4,6-H).

5.1.1.6. Methyl 2-(3-(8-bromooctyl)-2,5-dioxo-4,4-diphenylimidazolidin-1-yl)acetate (39). Ester 31 (9.72 g), 1,8-dibromooctane (39 mmol, $10.61 \mathrm{~g}$ ) were used. Reactants were stirred for $48 \mathrm{~h}$. White crystals of 39 (7.25 g, $14.07 \mathrm{mmol}, 47 \%)$ m.p. 74-75 ${ }^{\circ} \mathrm{C}, R_{f}$ (I):0.66. Anal. Calcd. for $\mathrm{C}_{26} \mathrm{H}_{31} \mathrm{BrN}_{2} \mathrm{O}_{4} \%$ : C, 60.58; $\mathrm{H}, 6.06$; $\mathrm{N}$, 5.43. Found: $\mathrm{C}, 59.96 ; \mathrm{H}, 5.97 ; \mathrm{N}, 5.50 .{ }^{1} \mathrm{H}$ NMR (DMSO- $d_{6}$ ) $\delta$ [ppm]: 0.71 (qu def, $\left.2 \mathrm{H}, \mathrm{N} 1-\mathrm{C}_{3} \mathrm{H}_{6}-\mathrm{CH}_{2}\right), 0.88-0.99(\mathrm{~m}, 6 \mathrm{H}$, $\mathrm{Br}-\mathrm{C}_{2} \mathrm{H}_{4}-\mathrm{CH}_{2}-\mathrm{CH}_{2}-\mathrm{CH}_{2}-\mathrm{CH}_{2}$ ), $1.16-1.26$ (qu def., $2 \mathrm{H}$, $\mathrm{N} 1-\mathrm{CH}_{2}-\mathrm{CH}_{2}$ ), $1 . \overline{6} 4-1.73$ (qu def., $2 \mathrm{H}, \mathrm{Br}-\mathrm{CH}_{2}-\mathrm{CH}_{2}$ ), 3.24-3.29 (t def., $\left.2 \mathrm{H}, \overline{\mathrm{N}} 1-\mathrm{CH}_{2}\right), 3.44-3.48\left(\mathrm{t}, J=6.67 \mathrm{~Hz}, 2 \mathrm{H}, \mathrm{Br}-\mathrm{CH}_{2}\right), 3.70$ ( s, 3H, OCH $), 4.33\left(\mathrm{~s}, 2 \mathrm{H}, \mathrm{N} 3-\mathrm{CH}_{2}\right), 7.26-7.29(\mathrm{~m}, 4 \mathrm{H}, 2 \times \mathrm{Ph}-$ 3,5-H), 7.43-7.46 (m, 6H, $2 \times \mathrm{Ph}-2,4,6-\mathrm{H})$.

\subsubsection{General procedure for N1-substituted piperazine derivatives (16, 18-20, 41)}

An appropriate N1-substituted piperazine ( $7.5 \mathrm{mmol}), \mathrm{K}_{2} \mathrm{CO}_{3}$ $(3 \mathrm{~g})$, TEBA $(0.2 \mathrm{~g})$ were suspended in acetone $(15-20 \mathrm{ml})$ and stirred under reflux for 30 min. N-1-bromoalkyl- 5,5diphenylhydantoin derivatives 36-40 (7.5-8.5 mmol) dissolved in acetone $(20-23 \mathrm{ml})$ were added. The mixture was stirred under reflux for $3.5-8.5 \mathrm{~h}$ and stirring was continued at room temperature overnight. The inorganic precipitate was separated by filtration and washed with acetone $(3 \times 10 \mathrm{ml})$. Combined filtrates were evaporated. Pure compounds $(\mathbf{1 6}, \mathbf{1 8}-\mathbf{2 0}, \mathbf{4 1})$ in basic form were obtained from the residue using one of the following methods: (A)crystallization with methanol; (B)- the residue was dissolved in methylene chloride $(10-15 \mathrm{ml})$, washed with $1 \%$ solution of $\mathrm{HCl}$ $(2 \times 10-15 \mathrm{ml})$ and water $(2 \times 10 \mathrm{ml})$, dried with $\mathrm{Na}_{2} \mathrm{SO}_{4}$ anhydrous, evaporated to give a new residue that was crystallized with methanol; (C)- purification using chromatography column with solvent system (IV).

5.1.2.1. Ethyl 4-(4-(3-(2-methoxy-2-oxoethyl)-2,4-dioxo-5,5-diphenylimidazolidin-1-yl)butyl)piperazine-1-carboxylate (16). Methyl 2-(3-(4-bromobutyl)-2,5-dioxo-4,4-diphenylimidazolidin-1-yl)acetate $36(3.44 \mathrm{~g})$ in acetone $(23 \mathrm{ml})$ was used. Reactants were stirred under reflux for $7 \mathrm{~h}$. Method B gave white crystals of $\mathbf{1 6}(2.12 \mathrm{~g}$, $3.95 \mathrm{mmol}, 53 \%)$ m.p. $213{ }^{\circ} \mathrm{C}, R_{f}$ (II):0.49. Anal. Calcd. for $\mathrm{C}_{29} \mathrm{H}_{36} \mathrm{~N}_{4} \mathrm{O}_{6}$ : C, 64.91; H, 6.76; N, 10.44. Found: C, 65.11; H, 6.84; N, 
10.31. ${ }^{1} \mathrm{H}$ NMR (DMSO- $\left.d_{6}\right) \delta[\mathrm{ppm}]: 0.74-0.79\left(\mathrm{~m}, 2 \mathrm{H}, \mathrm{Pp}-\mathrm{CH}_{2} \mathrm{CH}_{2}\right)$, 1.15-1.19 (t def, 3H, CO- $\left.\mathrm{CH}_{2}-\mathrm{CH}_{3}\right), 1.32\left(\mathrm{~m}, 2 \mathrm{H}, \mathrm{N} 1-\mathrm{CH}_{2} \mathrm{CH}_{2}\right)$, 2.75-2.91 (m, 6H, Pp-CH $2,2 \times \mathrm{Pp}-2,6-\mathrm{H}), 3.15-3.28(\mathrm{~m}, \overline{4} \mathrm{H}$, $\left.\mathrm{N} 1-\mathrm{CH}_{2}, 2 \times \mathrm{Pp}-3,5-\mathrm{H}\right), 3.70\left(\mathrm{~s}, 3 \mathrm{H}, \mathrm{O}-\mathrm{CH}_{3}\right), 4.01-4.08(\mathrm{q}$, $\left.J=7.10 \mathrm{~Hz}, \mathrm{CO}-\mathrm{CH}_{2}\right), 4.35\left(\mathrm{~s}, 2 \mathrm{H}, \mathrm{N} 3-\mathrm{CH}_{2}\right), 7.27-7.31(\mathrm{~m}, 4 \mathrm{H}, 2 \times$ Ph-3, 5-H), 7.44-7.49 (m, 6H, 2× Ph-2,4,6-H). ${ }^{13} \mathrm{C}$ NMR $(75 \mathrm{MHz}$, DMSO-d6) $\delta$ [ppm]: 14.92, 24.9, 25.1, 41.1, 53.0, 61.8, 74.9, 128.5, $128.6,129.3,129.5,137.1,154.7,154.8,168.5,173.2$.

5.1.2.2. Ethyl 4-(5-(3-(2-methoxy-2-oxoethyl)-2,4-dioxo-5,5-diphenylimidazolidin-1-yl)pentyl)piperazine-1-carboxylate (18). Methyl 2-(3-(5-bromopentyl)-2,5-dioxo-4,4-diphenylimidazolidin-1-yl) acetate 37 (3.57 g) in acetone $(23 \mathrm{ml})$ was used. Reactants were stirred under reflux for $5 \mathrm{~h}$. Method A gave white crystals of $\mathbf{1 8}$ (3.00 g, $5.45 \mathrm{mmol}, 73 \%$ ) m.p. $125{ }^{\circ} \mathrm{C}, R_{f}$ (II):0.42. Anal. Calcd. for $\mathrm{C}_{30} \mathrm{H}_{38} \mathrm{~N}_{4} \mathrm{O}_{6} \times 0.66$ acetone $\times 0.33 \mathrm{CH}_{2} \mathrm{Cl}_{2} \%: \mathrm{C}, 62.73 ; \mathrm{H}, 6.85 ; \mathrm{N}$, 9.14. Found: $\mathrm{C}, 62.72 ; \mathrm{H}, 6.91 ; \mathrm{N}, 9.16 .{ }^{1} \mathrm{H}$ NMR (DMSO- $d_{6}$ ) $\delta$ [ppm]: $0.72-0.75\left(\mathrm{~m}, 2 \mathrm{H}, \mathrm{N} 1-\mathrm{C}_{2} \mathrm{H}_{4}-\mathrm{CH}_{2}\right), 0.84-0.94$ (qu, $\left.J=7.35 \mathrm{~Hz}, 2 \mathrm{H}, \mathrm{Pp}-\mathrm{CH}_{2}-\mathrm{CH}_{2}\right), 1.05-1.10\left(\overline{\mathrm{m}}, 2 \mathrm{H}, \mathrm{N} 1-\mathrm{CH}_{2} \mathrm{CH}_{2}\right)$, $1.12-1.17$ ( $\mathrm{t}$ def., $\left.3 \mathrm{H}, \mathrm{CO}-\mathrm{CH}_{2}-\mathrm{CH}_{3}\right), 1.95-2.00(\mathrm{t}, J=7.31 \mathrm{~Hz}, \overline{2} \mathrm{H}$, $\left.\mathrm{PpCH}_{2}\right), 2.15-2.18(\mathrm{t}, J=5 \mathrm{~Hz}, 4 \mathrm{H}, 2 \times \mathrm{Pp}-2,6-\mathrm{H}), 3.27-3.29(\mathrm{~m}$, $\left.6 \mathrm{H}, \mathrm{N} 1-\mathrm{CH}_{2}, 2 \times \mathrm{Pp}-3,5-\mathrm{H}\right) 3.70\left(\mathrm{~s}, 3 \mathrm{H}, \mathrm{O}-\mathrm{CH}_{3}\right), 3.96-4.03(\mathrm{q}$, $\left.J=7.09 \mathrm{~Hz}, \mathrm{CO}-\mathrm{CH}_{2}\right), 4.33\left(\mathrm{~s}, 2 \mathrm{H}, \mathrm{N} 3-\mathrm{CH}_{2}\right), 7.26-7.29(\mathrm{~m}, 4 \mathrm{H}, 2 \times$ $\mathrm{Ph}-3,5-\mathrm{H}), 7.43-7.46$ ( $\mathrm{m}, 6 \mathrm{H}, 2 \times \mathrm{Ph}-2,4,6-\mathrm{H}) .{ }^{13} \mathrm{C}$ NMR $(75 \mathrm{MHz}$, DMSO-d6) $\delta$ [ppm]: 15.0, 24.2, 25.9, 27.6, 41.9, 43.7, 52.8, 53.0, $57.8,61.1,74.9,128.6,129.2,129.4,137.2,154.6,155.0,168.4,173.3$.

5.1.2.3. Ethyl 4-(6-(3-(2-methoxy-2-oxoethyl)-2,4-dioxo-5,5-diphenylimidazolidin-1-yl)hexyl)piperazine-1-carboxylate (19). Methyl 2-(3-(6-bromohexyl)-2,5-dioxo-4,4-diphenylimidazolidin-1-yl) acetate 38 (3.66 g) in acetone $(23 \mathrm{ml})$ was used. Reactants were stirred under reflux for $7 \mathrm{~h}$. Method $\mathrm{C}$ gave white crystals of $\mathbf{1 9}$ (2.65 g, $4.69 \mathrm{mmol}, 63 \%$ ) m.p. $60{ }^{\circ} \mathrm{C}, \mathrm{R}_{\mathrm{f}}$ (II):0.47. Anal. Calcd. for $\mathrm{C}_{31} \mathrm{H}_{40} \mathrm{~N}_{4} \mathrm{O}_{6} \%$ : C, 65.94; H, 7.14; N, 9.92. Found: C, 65.73; H, 7.23; N, 9.90. ${ }^{1} \mathrm{H}$ NMR (DMSO- $\left.d_{6}\right) \delta[\mathrm{ppm}]: 0.72\left(\mathrm{~m}, 2 \mathrm{H}, \mathrm{Pp}-\mathrm{C}_{2} \mathrm{H}_{4}-\mathrm{CH}_{2}\right)$, 0.89-0.92 (m, 4H, Pp- $\left.\mathrm{CH}_{2} \mathrm{CH}_{2}, \quad \mathrm{~N} 1-\mathrm{CH}_{2} \mathrm{CH}_{2}\right), \quad 1.13-1.17$ (t, $J=7.04 \mathrm{~Hz}, 3 \mathrm{H}, \mathrm{CO}-\mathrm{CH}_{2}-\mathrm{CH}_{3}$ ), 2.07-2.12 (t def., $2 \mathrm{H}, \mathrm{Pp}-\mathrm{CH}_{2}$ ), 2.19-2.22 (t, $J=4.87 \mathrm{~Hz}, 4 \mathrm{H}, 2 \times \mathrm{Pp}-2,6-\mathrm{H}), 3.27-3.29(\mathrm{~m}, 6 \mathrm{H}$, $\left.\mathrm{N} 1-\mathrm{CH}_{2}, 2 \times \mathrm{Pp}-3,5-\mathrm{H}\right) 3.70\left(\mathrm{~s}, 3 \mathrm{H}, \mathrm{O}-\mathrm{CH}_{3}\right), 3.96-4.04(\mathrm{q}$, $\left.J=7.09 \mathrm{~Hz}, \mathrm{CO}-\mathrm{CH}_{2}\right), 4.33\left(\mathrm{~s}, 2 \mathrm{H}, \mathrm{N} 3-\mathrm{CH}_{2}\right), 7.26-7.29(\mathrm{~m}, 4 \mathrm{H}, 2 \times$ $\mathrm{Ph}-3,5-\mathrm{H}), 7.43-7.46$ ( $\mathrm{m}, 6 \mathrm{H}, 2 \times \mathrm{Ph}-2,4,6-\mathrm{H})$.

5.1.2.4. Ethyl 4-(8-(3-(2-methoxy-2-oxoethyl)-2,4-dioxo-5,5-diphenylimidazolidin-1-yl)octyl)piperazine-1-carboxylate (20). Methyl 2-(3(8-bromooctyl)-2,5-dioxo-4,4-diphenylimidazolidin-1-yl)acetate $\mathbf{3 9}$ $(3.87 \mathrm{~g})$ in acetone $(23 \mathrm{ml})$ was used. Reactants were stirred under reflux for $8 \mathrm{~h}$. Method $\mathrm{C}$ gave beige crystals of $\mathbf{2 0}$ ( $1.23 \mathrm{~g}, 5.06 \mathrm{mmol}$, 67\%) m.p. $73{ }^{\circ} \mathrm{C}, R_{f}$ (II):0.51. Anal. Calcd. for $\mathrm{C}_{33} \mathrm{H}_{44} \mathrm{~N}_{4} \mathrm{O}_{6} \%$ : C, 66.87; $\mathrm{H}$, 7.48; N, 9.45. Found: C, 66.77; $\mathrm{H}, 7.73 ; \mathrm{N}, 9.46 .{ }^{1} \mathrm{H}$ NMR (DMSO- $d_{6}$ ) $\delta[\mathrm{ppm}]: 0.71\left(\mathrm{~m}, 2 \mathrm{H}, \mathrm{Pp}-\mathrm{C}_{3} \mathrm{H}_{6}-\mathrm{CH}_{2}\right), 0.88-0.89(\mathrm{~m}, 6 \mathrm{H}, \mathrm{Pp}-$ $\left.\mathrm{CH}_{2} \mathrm{CH}_{2} \mathrm{CH}_{2} \mathrm{CH}_{2} \mathrm{CH}_{2}\right), 1.06-1.09\left(\mathrm{~m}, 2 \mathrm{H}, \mathrm{N} 1-\mathrm{C}_{2} \mathrm{H}_{4}-\mathrm{CH}_{2}\right), 1.13-1.17$ (t, $\left.J=7.05 \overline{\mathrm{Hz}}, 3 \mathrm{H}, \mathrm{CO}-\mathrm{CH}_{2}-\mathrm{CH}_{3}\right), 1.25-1.32\left(\mathrm{~m}, 2 \overline{\mathrm{H}}, \mathrm{N} 1-\mathrm{CH}_{2} \mathrm{CH}_{2}\right)$, 2.15-2.20 (t def., $2 \mathrm{H}, \mathrm{Pp}-\mathrm{CH}_{2}$ ), 2.23-2.26 (t def, $4 \mathrm{H}, 2 \times \mathrm{Pp}-2,6-\mathrm{H}$ ), 3.23-3.25 (m, 6H, N1- $\left.\mathrm{CH}_{2}, 2 \times \mathrm{Pp}-3,5-\mathrm{H}\right) 3.70\left(\mathrm{~s}, 3 \mathrm{H}, \mathrm{O}-\mathrm{CH}_{3}\right)$, $3.96-4.04$ (q, $\left.J=7.09 \mathrm{~Hz}, \mathrm{CO}-\mathrm{CH}_{2}\right), 4.33\left(\mathrm{~s}, 2 \mathrm{H}, \mathrm{N} 3-\mathrm{CH}_{2}\right), 7.26-7.29$ (m, 4H, 2× Ph-3,5-H), 7.43-7.45 (m, 6H, 2× Ph-2,4,6-H).

5.1.2.5. 5,5-Diphenyl-1-(4-(4-phenylpiperazin-1-yl)butyl)-3-

tritylimidazolidine-2,4-dione (41). N-phenylpiperazine $(1.08 \mathrm{~g})$ in acetone $(20 \mathrm{ml})$ and compound $\mathbf{4 0}(5.31 \mathrm{~g}, 8.5 \mathrm{mmol})$ in acetone $(20 \mathrm{ml})$ were refluxed for $3.5 \mathrm{~h}$. Method A gave white crystals of compound 41 (3.12 g, 4.38 mmol, 59\%) m.p. 198-199 ${ }^{\circ} \mathrm{C}, R_{f}$ (II):0.8. Anal. Calcd. for $\mathrm{C}_{48} \mathrm{H}_{46} \mathrm{~N}_{4} \mathrm{O}_{2} \%$ : C, 81.10; $\mathrm{H}, 6.52 ; \mathrm{N}, 7.88$. Found: C, 80.97; H, 6.62; N, 7.79. ${ }^{1} \mathrm{H}$ NMR (DMSO- $\left.d_{6}\right) \delta[\mathrm{ppm}]: 0.62(\mathrm{qu}$, $\left.J=7.40 \mathrm{~Hz}, 2 \mathrm{H}, \mathrm{Pp}-\mathrm{CH}_{2} \mathrm{CH}_{2}\right), 0.95\left(\mathrm{qu}, J=7.40 \mathrm{~Hz}, 2 \mathrm{H}, \mathrm{N} 1-\mathrm{CH}_{2} \mathrm{CH}_{2}\right)$, $1.87\left(\mathrm{t}, J=7.18 \mathrm{~Hz}, 2 \mathrm{H}, \mathrm{Pp}-\mathrm{CH}_{2}\right), 2.22(\mathrm{t}, J=4.62 \mathrm{~Hz}, 4 \mathrm{H}, \mathrm{Pp}-2,6-\mathrm{H})$, $2.97(\mathrm{t}, J=4.80 \mathrm{~Hz}, 4 \mathrm{H}, \mathrm{Pp}-3,5-\mathrm{H}), 3.17\left(\mathrm{t}, J=7.18 \mathrm{~Hz}, 2 \mathrm{H}, \mathrm{N} 1-\mathrm{CH}_{2}\right)$, $6.72(\mathrm{t}, J=7.30 \mathrm{~Hz}, 1 \mathrm{H}, \mathrm{PpPh}-4-\mathrm{H}) 6.87-6.98$ (m, 7H, PpPh-2,3,5,6$\mathrm{H}$, trtPh-4-H), 7.16-7.35 (m, 16H, 5× Ph-3,5-H, 3× trtPh-2,6-H), 7.36-7.44 (m, 6H, 2× C5-Ph-2,4,6-H).

\subsubsection{Synthesis of methyl 2-(2,4-dioxo-5,5-diphenyl-1-(8-(piperazin- 1-yl)octyl)imidazolidin-3-yl)acetate (21)}

Piperazine (1.03 g), acetone ( $15 \mathrm{ml}), \mathrm{K}_{2} \mathrm{CO}_{3}$ (1.66 g), ester 39 $(2.06 \mathrm{~g})$ in acetone $(10 \mathrm{ml})$ were used. Reactants were stirred under reflux for $5 \mathrm{~h}$. The inorganic precipitate was separated by filtration. The filtrate was evaporated, the residue was dissolved in methylene chloride $(10 \mathrm{ml})$ washed with aqua $(3 \times 10 \mathrm{ml})$, dried with $\mathrm{Na}_{2} \mathrm{SO}_{4}$ anhydrous, evaporated to give a new residue that was purified using chromatography column with combined solvent system (V and $\mathrm{MeOH})$. White crystals of $21(0.11 \mathrm{~g}, 0.21 \mathrm{mmol}, 5 \%)$ m.p. $79^{\circ} \mathrm{C}$, $R_{f}$ (II):0.14. Anal. Calcd. for $\mathrm{C}_{30} \mathrm{H}_{40} \mathrm{~N}_{4} \mathrm{O}_{4} \%$ : C, 69.20; H, 7.74; N, 10.76; Found: C, 68.82; $\mathrm{H}, 7.80 ; \mathrm{N}, 10.45 .{ }^{1} \mathrm{H}$ NMR (DMSO- $\left.d_{6}\right) \delta[\mathrm{ppm}]: 0.71$ $\left(\mathrm{m}, \quad 2 \mathrm{H}, \quad \mathrm{Pp}-\mathrm{C}_{3} \mathrm{H}_{6}-\mathrm{CH}_{2}\right), \quad 0.90-1.08\left(\mathrm{~m}, \quad 6 \mathrm{H}, \quad \mathrm{Pp}-\mathrm{C}_{2} \mathrm{H}_{4}-\mathrm{CH}_{2}\right.$, $\left.\mathrm{N} 1-\mathrm{C}_{2} \mathrm{H}_{4}-\mathrm{CH}_{2} \mathrm{CH}_{2}\right), 1.12\left(\mathrm{~m}, 2 \mathrm{H}, \mathrm{Pp}-\mathrm{CH}_{2}-\mathrm{CH}_{2}\right), 1.31(\mathrm{~m}, \overline{2 \mathrm{H}}$, $\left.\mathrm{N} 1-\mathrm{CH}_{2} \mathrm{CH}_{2}\right), 2.01-2.39\left(\mathrm{~m}, 7 \mathrm{H}, \mathrm{Pp}-\mathrm{CH}_{2}, 2 \times \mathrm{Pp}-2,6-\mathrm{H}, \mathrm{Pp}-\mathrm{N}-\mathrm{H}\right)$, 3.23-3.26 ( $\left.\mathrm{m}, 6 \mathrm{H}, 2 \times \mathrm{Pp}-3,5-\mathrm{H}, \mathrm{N} 1-\mathrm{CH}_{2}\right), 3.70\left(\mathrm{~s}, 3 \mathrm{H}, \mathrm{O}-\mathrm{CH}_{3}\right), 4.33$ (s, 2H, N3- $\left.\mathrm{CH}_{2}\right), 7.26-7.29(\mathrm{~m}, 4 \mathrm{H}, 2 \times \mathrm{Ph}-3,5-\mathrm{H}), 7.43-7.45(\mathrm{~m}, 6 \mathrm{H}$, $2 \times \mathrm{Ph}-2,4,6-\mathrm{H}) .{ }^{13} \mathrm{C}$ NMR (75 MHz, DMSO-d6) $\delta$ [ppm]: 26.2, 27.0, 27.6, 28.6, 28.9, 42.0, 52.8, 53.0, 58.0, 74.9, 128.6, 129.2, 129.3, 137.2, $154.6,168.4,173.3$.

\subsubsection{Synthesis of 5,5-diphenyl-1-(4-(4-phenylpiperazin-1-yl) butyl)imidazolidine-2,4-dione (1)}

Compound $34(2.00 \mathrm{~g}, 2.76 \mathrm{mmol})$ was dissolved in methylene chloride $(20 \mathrm{ml})$. A 90\%-concentrated aqueous solution of TFA $(18 \mathrm{ml})$ was added and the mixture was stirred at room temperature for $20 \mathrm{~h}$. Then, the mixture was washed with water $(3 \times 20 \mathrm{ml})$, dried with $\mathrm{K}_{2} \mathrm{CO}_{3}$ anhydrous and evaporated. A residue was purified by column chromatography using methylene chloride-acetone (10:1) to give compound 1 (0.20 g, $0.42 \mathrm{mmol}, 15.2 \%)$, m.p. 187-188 ${ }^{\circ} \mathrm{C}, R_{f}$ (II):0.39. Anal. Calcd. for $\mathrm{C}_{30} \mathrm{H}_{34} \mathrm{~N}_{4} \mathrm{O}_{2}$ : C, 74.66; $\mathrm{H}$, 7.10; N, 11.61. Found: C, 74.81; H, 7.12; N, 11.54. ${ }^{1} \mathrm{H}$ NMR (DMSO-d 6 ) $\delta$ [ppm]: $0.65-0.75$ (def. qu, $2 \mathrm{H}, \mathrm{Pp}-\mathrm{CH}_{2}-\mathrm{CH}_{2}$ ), 1.00-1.10( def.qu, $2 \mathrm{H}, \mathrm{CH}_{2}-\mathrm{CH}_{2}-$ hyd $), 1.94\left(\mathrm{t}, J=7.18 \mathrm{~Hz}, 2 \mathrm{H}, \mathrm{Pp}-\mathrm{CH}_{2}-\mathrm{CH}_{2}\right), 2.26(\mathrm{t}$, $J=4.75 \mathrm{~Hz}, 4 \mathrm{H}, \mathrm{Pp}-2,6-\mathrm{H}), 2.98(\mathrm{t}, J=4.87 \mathrm{~Hz}, 4 \mathrm{H}, \overline{\mathrm{Pp}}-3,5-\mathrm{H}), 3.09(\mathrm{t}$, $\left.J=7.18 \mathrm{~Hz}, 2 \mathrm{H}, \mathrm{CH}_{2}-\mathrm{CH}_{2}-\mathrm{hyd}\right), 6.71(\mathrm{t}, J=7.18 \mathrm{~Hz}, 1 \mathrm{H}, \mathrm{PpPh}-4 \mathrm{H})$, $6.86(\mathrm{~d}, J=7.69 \mathrm{~Hz}, \overline{\mathrm{H}}, \mathrm{PpPh}-2.6 \mathrm{H}), 7.13-7.20(\mathrm{~m}, 6 \mathrm{H}, 2 \times \mathrm{Ph}-$ 2,4,6H), 7.28-7.40(m, 6H, PpPh-3,5-H, 2× Ph-3, 5-H), 8.32 (s, 1H, $\mathrm{N} 3-\mathrm{H})$.

\subsubsection{Synthesis of piperazine derivatives of 3-hydantoinacetic acid $(\mathbf{9}, 17)$}

5.1.5.1. Synthesis of 2-(3-(4-(4-(2-methoxyphenyl)piperazin-1-yl) butyl)-2,5-dioxo-4,4-diphenylimidazolidin-1-yl)acetic acid hydrochloride (9). A suspension of methyl 2-(3-(4-(4-(2-methoxyphenyl) piperazin-1-yl)butyl)-2,5-dioxo-4,4-diphenylimidazolidin-1-yl) acetate $42(1.4 \mathrm{mmol}, 0.8 \mathrm{~g})$ in $\mathrm{MeOH}(5 \mathrm{~mL})$ and $\mathrm{H}_{2} \mathrm{O}(5 \mathrm{~mL})$ was treated with $\mathrm{KOH}(8.9 \mathrm{mmol}, 0.50 \mathrm{~g})$, stirred at room temperature for $2 \mathrm{~h}$, diluted with $\mathrm{H}_{2} \mathrm{O}(10 \mathrm{~mL})$, acidified to $\mathrm{pH}=3(35 \% \mathrm{HCl})$, extracted with $\mathrm{CH}_{2} \mathrm{Cl}_{2}(3 \times 5 \mathrm{ml})$, dried with $\mathrm{Na}_{2} \mathrm{SO}_{4}$ anhydrous and evaporated. The residue was dissolved in absolute $\mathrm{EtOH}(20 \mathrm{ml})$ and saturated with gaseous $\mathrm{HCl}$ to give a white powder of $9(0.63 \mathrm{~g}$, $1.1 \mathrm{mmol}, 78.6 \%$ ), m.p. $186-187{ }^{\circ} \mathrm{C}, R_{f}$ (III): 0.83. Anal. Calcd. for $\mathrm{C}_{32} \mathrm{H}_{36} \mathrm{~N}_{4} \mathrm{O}_{5} \times \mathrm{HCl}: \mathrm{C}, 64.80 ; \mathrm{H}, 6.29 ; \mathrm{N}, 9.45$. Found: C, 64.67; H, 6.29; $\mathrm{N}$, 9.51. ${ }^{1} \mathrm{H}$ NMR (DMSO- $d_{6}$ ) $\delta$ [ppm]: $0.78-0.82$ (qu def., $2 \mathrm{H}$, $\mathrm{PpCH}_{2} \mathrm{CH}_{2}$ ), 1.40 (br. s, $2 \mathrm{H}, \mathrm{PpCH}_{2} \mathrm{CH}_{2} \mathrm{CH}_{2}$ ), 2.78 (br. s, $2 \mathrm{H}, \mathrm{Pp}-\mathrm{CH}_{2}$ ), 2.92-3.05 (m, 4H, Pp-2, 6-H), 3.32-3.43 (m, 6H, Pp-3, 5-H, N1- $\mathrm{CH}_{2}$ ), $3.77\left(\mathrm{~s}, 3 \mathrm{H}, \mathrm{OCH}_{3}\right), 4.20\left(\mathrm{~s}, 2 \mathrm{H}, \mathrm{N} 3-\mathrm{CH}_{2}\right), 6.85-7.03(\mathrm{~m}, 4 \mathrm{H}, \mathrm{PpPh})$ 7.15-7.48 (m, 10H, $2 \times \mathrm{Ph}), 10.59$ (br. s, $\left.1 \mathrm{H}, \mathrm{NH}^{+}\right) .{ }^{13} \mathrm{C}$ NMR $(75 \mathrm{MHz}$, 
DMSO-d6) $\delta$ [ppm]: 20.5, 25.2, 47.2, 51.3, 55.1, 55.8, 74.9, 112.4, 118.7, $121.3,124.0,128.7,129.3,129.4,137.3,139.7,152.3,154.9,169.0,173.3$.

5.1.5.2. Synthesis of 2-(1-(4-(4-(ethoxycarbonyl)piperazin-1-yl) butyl)-2,4-dioxo-5,5-diphenylimidazolidin-3-yl)acetic acid (17). A suspension of ethyl 4-(4-(3-(2-methoxy-2-oxoethyl)-2,4-dioxo5,5-diphenylimidazolidin-1-yl)butyl)piperazine-1-carboxylate $\mathbf{1 6}$ $(1.96 \mathrm{mmol}, 1.05 \mathrm{~g})$ in $\mathrm{MeOH}(4 \mathrm{~mL})$ and $\mathrm{H}_{2} \mathrm{O}(4 \mathrm{~mL})$ was treated with $\mathrm{KOH}$ ( $10.7 \mathrm{mmol}, 0.6 \mathrm{~g}$ ), stirred at room temperature for $3 \mathrm{~h}$, acidified to $\mathrm{pH}=6(35 \% \mathrm{HCl})$ and stirred overnight. Then, the suspension was diluted with $\mathrm{H}_{2} \mathrm{O}(10 \mathrm{~mL})$ and extracted with methylene chloride $(3 \times 10 \mathrm{ml})$. The combined organic fractions were dried with anhydrous $\mathrm{Na}_{2} \mathrm{SO}_{4}$, separated from the drying agent and evaporated to give bright crystals of $17(0.57 \mathrm{~g}, 1.1 \mathrm{mmol}$, 56\%), m.p.140-142 ${ }^{\circ} \mathrm{C}, R_{f}(\mathrm{~V}): 0.68$. Anal. Calcd. for $\mathrm{C}_{28} \mathrm{H}_{34} \mathrm{~N}_{4} \mathrm{O}_{6} \%$ : C, 64.35; H, 6.56; N, 10.72. Found: C, 64.57; H, 6.59; N, 10.58. ${ }^{1} \mathrm{H}$ NMR (DMSO- $d_{6}$ ) $\delta$ [ppm]: 0.77-0.87 (qu def., $2 \mathrm{H}, \mathrm{Pp}-\mathrm{CH}_{2} \mathrm{CH}_{2}$ ), 1.16-1.21 (t, $\left.J=7.08 \mathrm{~Hz}, 3 \mathrm{H}, \mathrm{CO}-\mathrm{CH}_{2}-\mathrm{CH}_{3}\right), 1.23-1.26\left(\mathrm{~m}, 2 \mathrm{H}, \mathrm{N} 1-\mathrm{CH}_{2} \mathrm{CH}_{2}\right)$, 2.72-2.78 ( $\mathrm{m}, 4 \mathrm{H}, 2 \times \mathrm{Pp}-2,6-\mathrm{H}), 2.91\left(\mathrm{~m}, 2 \mathrm{H}, \mathrm{Pp}-\mathrm{CH}_{2}\right), 3.32-3.37$ (m, 6H, N1- $\left.\mathrm{CH}_{2}, 2 \times \mathrm{Pp}-3,5-\mathrm{H}\right), 4.02-4.09$ (q, $\left.J=7.08 \mathrm{~Hz}, \mathrm{CO}-\mathrm{CH}_{2}\right)$, $4.21\left(\mathrm{~s}, 2 \mathrm{H}, \mathrm{N} 3-\mathrm{CH}_{2}\right), 7.18-7.21(\mathrm{~m}, 1 \mathrm{H}, \mathrm{Ph}-4-\mathrm{H}), 7.29-7.32(\mathrm{~m}, 3 \mathrm{H}$, Ph-2,6-H, Ph-2-H), 7.38-7.49 (m, 6H, Ph-4,6-H, $2 \times$ Ph-3,5-H). ${ }^{13} \mathrm{C}$ NMR (75 MHz, DMSO-d6) $\delta$ [ppm]: 14.9, 21.2, 25.3, 41.24, 41.4, 51.1, $61.6,74.9,128.7,129.3,137.2,137.3,154.8,155.0,169.1,173.4$.

\subsubsection{General procedure for O-acetylated derivatives (10 and 11)}

Arylpiperazine derivative of hydantoin with free hydroxyl group 4 or $7(1.4-3.1 \mathrm{mmol})$ was slowly refluxed with acetic anhydride $(4-10 \mathrm{ml})$ for $1-20 \mathrm{~min}$. The solution was stored at low temperature for 2-10 days to give a white precipitate of basic form of the product (10b or 11b), which was converted into hydrochloride form (10 or 11) by dissolving in methanol and saturation with gaseous $\mathrm{HCl}$.

5.1.6.1. 1-(3-methyl-2,4-dioxo-5,5-diphenylimidazolidin-1-yl)-3-(4phenylpiperazin-1-yl)propan-2-yl acetate (10b). Compound 4 (1.5 g, $3.1 \mathrm{mmol})$ and $\mathrm{Ac}_{2} \mathrm{O}(10 \mathrm{ml})$ were refluxed for $15 \mathrm{~min}$, cooled $(0-$ $\left.4{ }^{\circ} \mathrm{C}\right)$ for 2 days to give white powder of $\mathbf{1 0 b}(1.15 \mathrm{~g}, 2.2 \mathrm{mmol}$, 70.5\%), m.p. $178-180{ }^{\circ} \mathrm{C}, R_{f}(\mathrm{III}): 0.87$. Anal. Calcd. for $\mathrm{C}_{31} \mathrm{H}_{34} \mathrm{~N}_{4} \mathrm{O}_{4}: \mathrm{C}$, 70.70; H, 6.51; N, 10.64. Found: C, 70.59; H, 6.53; N, 10.61. ${ }^{1} \mathrm{H}$ NMR $\left(\mathrm{DMSO}_{-} \mathrm{d}_{6}\right) \delta[\mathrm{ppm}]: 1.72\left(\mathrm{~s}, 3 \mathrm{H}, \mathrm{CH}_{3} \mathrm{Ac}\right), 2.16-2.18(\mathrm{~d}, J=6.41 \mathrm{~Hz}$, 2H, Pp- $\mathrm{CH}_{2}$ ), 2.20-2.29 (m, 4H, Pp-2, 6-H), 2.94-2.96 (m, 7H, Pp-3, $\left.5-\mathrm{H}, \mathrm{N} 3-\mathrm{CH}_{3}\right), 3.55$ (d, $\left.J=6.16 \mathrm{~Hz}, 2 \mathrm{H}, \mathrm{N} 1-\mathrm{CH}_{2}\right), 4.43-4.48$ (qu, $J=6.16 \mathrm{~Hz}, 1 \mathrm{H}, \mathrm{CH}), 6.71-6.76(\mathrm{t}, J=7.18 \mathrm{~Hz}, 1 \mathrm{H}, \mathrm{PpPh}-4-\mathrm{H})$, 6.85-6.88 (d, J=7.95 Hz, 2H, PpPh-2, 6-H), 7.14-7.24 (m, 6H, PpPh3,5-H, $2 \times \mathrm{Ph}-3,5-\mathrm{H}), 7.41-7.46$ (m, 6H, $2 \times \mathrm{Ph}-2,4,6-\mathrm{H})$.

5.1.6.2. 1-(3-methyl-2,4-dioxo-5,5-diphenylimidazolidin-1-yl)-3-(4phenylpiperazin-1-yl)propan-2-yl acetate hydrochloride (10). Compound 10b $(0.9 \mathrm{~g}, 1.71 \mathrm{mmol})$ in $\mathrm{MeOH}(15 \mathrm{ml})$ was saturated with gaseous $\mathrm{HCl}$ to give white crystals of $\mathbf{1 0}(1 \mathrm{~g}, 1.65 \mathrm{mmol}, 96 \%)$ m.p. $180-184{ }^{\circ} \mathrm{C}, R_{f}$ (III):0.87. Anal. Calcd. for $\mathrm{C}_{31} \mathrm{H}_{34} \mathrm{~N}_{4} \mathrm{O}_{4} \times 2 \mathrm{HCl} \times 0.5$ $\mathrm{CH}_{3} \mathrm{OH}$ : C, 61.78; H, 6.14; N, 9.22. Found: C, 61.78; H, 6.17; N, 9.28. ${ }^{1} \mathrm{H}$ NMR: for $5\left(\right.$ DMSO$\left.d_{6}\right) \delta[\mathrm{ppm}]: 1.86\left(\mathrm{~s}, 3 \mathrm{H}, \mathrm{COCH}_{3}\right), 2.71-2.73(\mathrm{~m}, 1 \mathrm{H}$, $\mathrm{CH}), 2.88-2.92\left(\mathrm{~m}, 2 \mathrm{H}, \mathrm{Pp}-\mathrm{CH}_{2}\right), 2.97\left(\mathrm{~s}, 3 \mathrm{H}, \mathrm{N} 3-\mathrm{CH}_{3}\right), 3.08-3.16(\mathrm{~m}$, $4 \mathrm{H}, \mathrm{Pp}-2,6-\mathrm{H}), 3.21-3.31\left(\mathrm{~m}, 2 \mathrm{H}, \mathrm{N} 1-\mathrm{CH}_{2}\right), 3.63-3.72$ (m, 4H, Pp-3, 5$\mathrm{H}$ ), $6.82(\mathrm{t}, J=7.30 \mathrm{~Hz}, 1 \mathrm{H}, \mathrm{PpPh}-4-\mathrm{H}), 6.95$ (d, $J=7.95 \mathrm{~Hz}, 2 \mathrm{H}, \mathrm{PpPh}-2$, 6-H), 7.19-7.27 (m, 6H, PpPh-3,5-H, 2× Ph-3,5-H), 7.45-7.46 (m, 6H, $2 \times \mathrm{Ph}-2,4,6-\mathrm{H}$ ), 10.94 (br. s, $1 \mathrm{H}, \mathrm{NH}^{+}$).

5.1.6.3. Methyl 2-(3-(2-acetoxy-3-(4-phenylpiperazin-1-yl)propyl)2,5-dioxo-4,4-diphenylimidazolidin-1-yl)acetate (11b). Compound 7 $(1.3 \mathrm{~g}, 2.4 \mathrm{mmol})$ and $\mathrm{Ac}_{2} \mathrm{O}(10 \mathrm{ml})$ were refluxed for $20 \mathrm{~min}$, cooled $\left(0-4{ }^{\circ} \mathrm{C}\right)$ for 3 days to give white powder of $\mathbf{1 1 b}(1.25 \mathrm{~g}, 2.1 \mathrm{mmol}$, 89.1\%), m.p. $196-198{ }^{\circ} \mathrm{C}, R_{f}$ (III):0.81. Anal. Calcd. for $\mathrm{C}_{33} \mathrm{H}_{36} \mathrm{~N}_{4} \mathrm{O}_{6}$ : C, 67.79; H, 6.21; N, 9.58. Found: C, 67.80; H, 6.24; N, 9.62.
${ }^{1} \mathrm{H}$ NMR (DMSO- $\left.d_{6}\right) \delta[\mathrm{ppm}]: 1.72\left(\mathrm{~s}, 3 \mathrm{H}, \mathrm{CH}_{3} \mathrm{Ac}\right), 2.15(\mathrm{~d}$, $\left.J=6.41 \mathrm{~Hz}, 2 \mathrm{H}, \mathrm{Pp}-\mathrm{CH}_{2}\right), 2.23-2.28$ (m, 4H, Pp-2, 6-H), 2.93-2.96 (t def., $4 \mathrm{H}, \mathrm{Pp}-3,5-\mathrm{H}), 3.56-3.64\left(\mathrm{~m}, 2 \mathrm{H}, \mathrm{N} 1-\mathrm{CH}_{2}\right), 3.68\left(\mathrm{~s}, 3 \mathrm{H}, \mathrm{OCH}_{3}\right)$ $4.34\left(2,2 \mathrm{H}, \mathrm{N} 3-\mathrm{CH}_{2}\right), 4.34-4.40(\mathrm{~m}, 1 \mathrm{H}, \mathrm{CH}), 6.71(\mathrm{t}, J=7.50 \mathrm{~Hz}, 1 \mathrm{H}$, PpPh-4-H), 6.85-6.88 (d, J = 7.50 Hz, 2H, PpPh-2, 6-H), 7.14-7.19 (t def., 2H, PpPh-3,5-H), 7.23-7.29 (m, 4H, 2× Ph-3,5-H), 7.44-7.48 (m, 6H, $2 \times \mathrm{Ph}-2,4,6-\mathrm{H}) .{ }^{13} \mathrm{C}$ NMR (75 MHz, DMSO-d6) $\delta$ [ppm]: 21.1, $41.05,43.9,48.7,52.9,53.3,59.1,68.9,75.4,115.8,119.2,128.8,129.2$, $129.4,136.8,151.5,155.3,169.7,173.0$.

5.1.6.4. Methyl 2-(3-(2-acetoxy-3-(4-phenylpiperazin-1-yl)propyl)2,5-dioxo-4,4-diphenylimidazolidin-1-yl)acetate hydrochloride (11). Compound 11b $(0.85 \mathrm{~g}, 1.5 \mathrm{mmol})$ in dry $\mathrm{MeOH}(15 \mathrm{ml})$ was saturated with gaseous $\mathrm{HCl}$ to give white crystals of $\mathbf{9}(0.9 \mathrm{~g}, 1.38 \mathrm{mmol}$, 92\%) m.p. $162-164{ }^{\circ} \mathrm{C}, \quad R_{f} \quad$ (III):0.81. Anal. Calcd. for $\mathrm{C}_{31} \mathrm{H}_{34} \mathrm{~N}_{4} \mathrm{O}_{4} \times \mathrm{HCl} \times \mathrm{CH}_{3} \mathrm{OH}: \mathrm{C}, 62.52 ; \mathrm{H}, 6.33 ; \mathrm{N}, 8.58$. Found: $\mathrm{C}$, 62.56; $\mathrm{H}, 6.32 ; \mathrm{N}, 8.54$.

${ }^{1} \mathrm{H}$ NMR (DMSO- $\left.d_{6}\right) \delta[\mathrm{ppm}]: 1.83\left(\mathrm{~s}, 3 \mathrm{H}, \mathrm{CH}_{3} \mathrm{Ac}\right.$ ), 2.71 (br. s, $1 \mathrm{H}$, $\left.\mathrm{N} 1-\mathrm{CH}_{2 \mathrm{a}}\right), 3.01-3.20\left(\mathrm{~m}, 7 \mathrm{H}, \mathrm{Pp}-\mathrm{CH}_{2}, \mathrm{Pp}-2, \quad 6-\mathrm{H}, \mathrm{N} 1-\mathrm{CH}_{2 \mathrm{e}}\right)$, 3.60-3.64 (m, 4H, Pp-3, 5-H), $3.66\left(\mathrm{~s}, 3 \mathrm{H}, \mathrm{OCH}_{3}\right), 3.73-3.81(\mathrm{~m}, 1 \mathrm{H}$, $\mathrm{CH}), 4.33\left(\mathrm{~s}, 2 \mathrm{H}, \mathrm{N} 3-\mathrm{CH}_{2}\right), 6.82(\mathrm{t}, J=6.18 \mathrm{~Hz}, 1 \mathrm{H}, \mathrm{PpPh}-4-\mathrm{H}), 6.95$ (d, $J=7.95 \mathrm{~Hz}, 2 \mathrm{H}, \mathrm{PpPh}-2,6-\mathrm{H}), 7.21-7.29$ (m, 6H, 2× Ph-3,5-H, PpPh-3,5-H), 7.47-7.52 (m, 6H, 2× Ph-2,4,6-H), 10.90 (br. s, $1 \mathrm{H}$, $\mathrm{NH}^{+}$).

\subsubsection{General procedure for hydantoin derivatives of 1,5,7-triazabicyclo} [4.4.0]dec-5-ene (22-25)

The mixture of 1,5,7-triazabicyclo[4.4.0]dec-5-ene (1.5 mmol, $210 \mathrm{mg})$, TВAB $(0.15 \mathrm{mmol}, 48 \mathrm{mg}$ ) and potassium carbonate $(400 \mathrm{mg})$ in acetone $(4 \mathrm{~mL})$ was stirred under reflux for $1 \mathrm{~h}$, then an appropriate bromide $\mathbf{3 5 - 3 8}$ ( $1 \mathrm{mmol})$ in acetone $(1 \mathrm{~mL})$ was added. The mixture was refluxed for $6-7 \mathrm{~h}$. After cooling the mixture was filtered and the mother liquor was evaporated in vacuo affording colorless oil. Hydrochlorides were obtained using an ether solution of hydrogen chloride with methanol as co-solvent.

\subsubsection{2-(3-(3-(2,3,4,6,7,8-hexahydro-1H-pyrimido[1,2-a]pyr-} imidin-1-yl)propyl)-2,5-dioxo-4,4-diphenylimidazolidin-1-yl)acetic acid hydrochloride (22). Raw product was purified by column chromatography (choroform:methanol). Colorless dense oil, yield 22\%; Anal. Calcd. for $\mathrm{C}_{27} \mathrm{H}_{32} \mathrm{ClN}_{5} \mathrm{O}_{4}$ : C, 61.65; $\mathrm{H}, 6.13 ; \mathrm{N}, 13.31$. Found: C, 61.44; H, 6.15; N, 13.10. ${ }^{1} \mathrm{H}$ NMR (200 MHz, MeOD): $\delta 0.72-0.86\left(\mathrm{~m}, 2 \mathrm{H}, \mathrm{CH}_{2}\right), 1.18-1.29\left(\mathrm{~m}, 2 \mathrm{H}, \mathrm{CH}_{2}\right), 1.92-2.01(\mathrm{~m}, 4 \mathrm{H}$, $\left.\mathrm{CH}_{2}\right), 3.10-3.30\left(\mathrm{~m}, 8 \mathrm{H}, \mathrm{CH}_{2}\right), 3.53\left(\mathrm{t}, \mathrm{J}=9 \mathrm{~Hz}, 2 \mathrm{H}, \mathrm{CH}_{2}\right), 4.00(\mathrm{~s}, 2 \mathrm{H}$, $\left.\mathrm{CH}_{2}\right), 7.34-7.42(\mathrm{~m}, 10 \mathrm{H}, \mathrm{Ar})$.

5.1.7.2. 2-(3-(4-(2,3,4,6,7,8-hexahydro-1H-pyrimido[1,2-a]pyrimidin-1-yl)butyl)-2,5-dioxo-4,4-diphenylimidazolidin-1-yl)acetic acid hydrochloride (23). Raw product was purified by column chromatography (chloroform:methanol). White solid, yield $81 \%$; Anal. Calcd. for $\mathrm{C}_{28} \mathrm{H}_{34} \mathrm{ClN}_{5} \mathrm{O}_{4}$ : C, 62.27; $\mathrm{H}, 6.35 ; \mathrm{N}, 12.97$. Found: $\mathrm{C}$, 61.99; H, 6.37; N, 12.88. ${ }^{1} \mathrm{H}$ NMR (200 MHz, MeOD): $\delta 0.74-0.80(\mathrm{~m}$, $\left.2 \mathrm{H}, \mathrm{CH}_{2}\right), 1.19-1.28\left(\mathrm{~m}, 2 \mathrm{H}, \mathrm{CH}_{2}\right), 1.88-1.96\left(\mathrm{~m}, 4 \mathrm{H}, \mathrm{CH}_{2}\right), 3.06-3.26$ ( $\mathrm{m}, 10 \mathrm{H}, \mathrm{CH}_{2}$ ), 3.29-3.31 ( $\left.\mathrm{m}, 2 \mathrm{H}, \mathrm{CH}_{2}\right), 4.01$ (s, 2H, $\left.\mathrm{CH}_{2}\right), 7.39-7.42$ $(\mathrm{m}, 10 \mathrm{H}, \mathrm{Ar}) .{ }^{13} \mathrm{C}$ NMR $(200 \mathrm{MHz}, \mathrm{MeOD}) \delta[\mathrm{ppm}]: 20.4,20.5,23.3$, 24.9, 38.5, 39.5, 40.6, 46.0, 47.0, 47.4, 48.8, 75.2, 128.4, 128.6, 128.9, $136.9,150.3,156.0 .169 .0,173.9$.

\subsubsection{2-(3-(5-(2,3,4,6,7,8-hexahydro-1H-pyrimido[1,2-a]pyr-} imidin-1-yl)pentyl)-2,5-dioxo-4,4-diphenylimidazolidin-1-yl)acetic acid hydrochloride (24). Raw product was stirred in acetone at room temperature for $30 \mathrm{~min}$. White solid was filtrated off and recrystallized from ethanol, yield 20\%; Anal. Calcd. for $\mathrm{C}_{29} \mathrm{H}_{36} \mathrm{ClN}_{5} \mathrm{O}_{4}$ : C, 62.86; H, 6.55; N, 12.64. Found: C, 62.47; H, 6.56; $\mathrm{N}, 12.51 .{ }^{1} \mathrm{H}$ NMR (200 MHz, MeOD): $\delta 0.71-0.78\left(\mathrm{~m}, 2 \mathrm{H}, \mathrm{CH}_{2}\right)$, 
0.95-1.17 (m, 2H, $\left.\mathrm{CH}_{2}\right), 1.28-1.39\left(\mathrm{~m}, 2 \mathrm{H}, \mathrm{CH}_{2}\right), 1.95-2.01(\mathrm{~m}, 4 \mathrm{H}$, $\left.\mathrm{CH}_{2}\right), 3.11\left(\mathrm{t}, J=12 \mathrm{~Hz}, 2 \mathrm{H}, \mathrm{CH}_{2}\right), 3.26-3.46\left(\mathrm{~m}, 10 \mathrm{H}, \mathrm{CH}_{2}\right), 4.02(\mathrm{~s}$, $\left.2 \mathrm{H}, \mathrm{CH}_{2}\right), 7.40-7.44(\mathrm{~m}, 10 \mathrm{H}, \mathrm{Ar})$.

5.1.7.4. 2-(3-(6-(2,3,4,6,7,8-hexahydro-1H-pyrimido[1,2-a]pyrimidin-1-yl)hexyl)-2,5-dioxo-4,4-diphenylimidazolidin-1-yl)acetic acid hydrochloride (25). Raw product was stirred in acetone at room temperature for $30 \mathrm{~min}$. White solid was filtrated off and recrystallized from ethanol, yield 32\%; Anal. Calcd. for $\mathrm{C}_{30} \mathrm{H}_{38} \mathrm{ClN}_{5} \mathrm{O}_{4}$ : C, 63.42; H, 6.74; N, 12.33. Found: C, 63.10; H, 6.72; $\mathrm{N}, 12.16 .{ }^{1} \mathrm{H}$ NMR (200 MHz, MeOD): $\delta 0.83-0.89\left(\mathrm{~m}, 2 \mathrm{H}, \mathrm{CH}_{2}\right)$, 1.00-1.06 (m, $\left.4 \mathrm{H}, \mathrm{CH}_{2}\right), 1.35-1.41\left(\mathrm{~m}, 2 \mathrm{H}, \mathrm{CH}_{2}\right), 1.93-2.05(\mathrm{~m}, 4 \mathrm{H}$, $\left.\mathrm{CH}_{2}\right), 3.17\left(\mathrm{t}, J=10.5 \mathrm{~Hz}, 2 \mathrm{H}, \mathrm{CH}_{2}\right), 3.30-3.38\left(\mathrm{~m}, 10 \mathrm{H}, \mathrm{CH}_{2}\right), 4.02(\mathrm{~s}$, $\left.2 \mathrm{H}, \mathrm{CH}_{2}\right), 7.39-7.43$ ( $\left.\mathrm{m}, 10 \mathrm{H}, \mathrm{Ar}\right)$.

\subsubsection{General procedure for phthalimides (44-46)}

The mixture of phthalimide ( $1 \mathrm{mmol}, 185 \mathrm{mg})$, TBAB $(0.15 \mathrm{mmol}$, $48 \mathrm{mg}$ ) and potassium carbonate $(400 \mathrm{mg})$ in acetone $(4 \mathrm{~mL})$ was stirred under reflux for $30 \mathrm{~min}$, then an appropriate bromide 35, 36 or $38(1 \mathrm{mmol})$ in acetone $(1 \mathrm{~mL})$ was added and the mixture was refluxed for $2 \mathrm{~h}$. After cooling the mixture was filtered and the mother liquor was evaporated in vacuo. The residue was purified by column chromatography (petroleum ether:ethyl acetate).

5.1.8.1. Methyl 2-(3-(3-(1,3-dioxoisoindolin-2-yl)propyl)-2,5-dioxo4,4-diphenylimidazolidin-1-yl)acetate (44). White solid, yield 86\%; ${ }^{1} \mathrm{H}$ NMR (200 MHz, CDCl3): $\delta 0.82-0.91\left(\mathrm{~m}, 2 \mathrm{H}, \mathrm{CH}_{2}\right), 3.37-3.46(\mathrm{~m}$, $\left.4 \mathrm{H}, \mathrm{CH}_{2}\right), 3.76\left(\mathrm{~s}, 3 \mathrm{H}, \mathrm{CH}_{3}\right), 4.30\left(\mathrm{~s}, 2 \mathrm{H}, \mathrm{CH}_{2}\right), 7.17-7.37$ (m, 10H, Ar), $7.68-7.79$ (m, $4 \mathrm{H}, \mathrm{Ar})$.

5.1.8.2. Methyl 2-(3-(4-(1,3-dioxoisoindolin-2-yl)butyl)-2,5-dioxo4,4-diphenylimidazolidin-1-yl)acetate (45). White solid, yield 97\%; ${ }^{1} \mathrm{H}$ NMR (200 MHz, CDCl3): $\delta 0.77-0.87\left(\mathrm{~m}, 4 \mathrm{H}, \mathrm{CH}_{2}\right), 3.37-3.44(\mathrm{~m}$, $\left.4 \mathrm{H}, \mathrm{CH}_{2}\right), 3.78\left(\mathrm{~s}, 3 \mathrm{H}, \mathrm{CH}_{3}\right), 4.31\left(\mathrm{~s}, 2 \mathrm{H}, \mathrm{CH}_{2}\right), 7.17-7.38(\mathrm{~m}, 10 \mathrm{H}, \mathrm{Ar})$, 7.70-7.82 (m, 4H, Ar). ${ }^{13} \mathrm{C}$ NMR (200 MHz, CDCl3) $\delta$ [ppm]: 25.3, 25.7, 37.2, 39.9, 41.5, 52.7, 75.2, 123.1, 128.4, 128.8, 128.9, 132.2, 133.9, 136.8, 155.0, 167.6, 168.1, 173.5.

5.1.8.3. Methyl 2-(3-(6-(1,3-dioxoisoindolin-2-yl)hexyl)-2,5-dioxo4,4-diphenylimidazolidin-1-yl)acetate (46). White solid, yield 91\%; ${ }^{1} \mathrm{H}$ NMR (200 MHz, MeOD): $\delta 0.78-0.82\left(\mathrm{~m}, 2 \mathrm{H}, \mathrm{CH}_{2}\right), 0.97-1.01(\mathrm{~m}$, $\left.4 \mathrm{H}, \mathrm{CH}_{2}\right), 1.42-1.46\left(\mathrm{~m}, 2 \mathrm{H}, \mathrm{CH}_{2}\right), 3.2-3.39\left(\mathrm{~m}, 2 \mathrm{H}, \mathrm{CH}_{2}\right), 3.48-3.52$ $\left(\mathrm{m}, 2 \mathrm{H}, \mathrm{CH}_{2}\right), 3.77\left(\mathrm{~s}, 3 \mathrm{H}, \mathrm{CH}_{3}\right), 4.33\left(\mathrm{~s}, 2 \mathrm{H}, \mathrm{CH}_{2}\right), 7.30-7.42(\mathrm{~m}, 10 \mathrm{H}$, Ar), $7.79-7.90$ (m, 4H, Ar).

\subsubsection{General procedure for primary amines $\mathbf{2 6 - 2 8}$}

The mixture of an appropriate phthalimide 44-46 (1 mmol) and hydrazine monohydrate ( $1 \mathrm{mmol}, 50 \mathrm{mg}$ ) in anhydrous ethanol $(3 \mathrm{~mL})$ was refluxed for $4 \mathrm{~h}$. After cooling the reaction mixture was filtrated from white solid and the mother liquor was evaporated in vacuo affording yellow solid. Hydrochlorides were obtained using an ether solution of hydrogen chloride with methanol as cosolvent.

5.1.9.1. 2-(3-(3-Aminopropyl)-2,5-dioxo-4,4-diphenylimidazolidin-1yl)acetic acid hydrochloride (26). White solid, yield 73\%; Anal. Calcd. for $\mathrm{C}_{20} \mathrm{H}_{22} \mathrm{ClN}_{3} \mathrm{O}_{4}$ : C, 59.48; $\mathrm{H}, 5.49 ; \mathrm{N}, 10.40$. Found: C, 59.21; $\mathrm{H}, 5.47$; N, 10.67. ${ }^{1} \mathrm{H}$ NMR (200 MHz, MeOD): $\delta 1.14-1.27(\mathrm{~m}, 2 \mathrm{H}$, $\left.\mathrm{CH}_{2}\right), 2.57-2.64\left(\mathrm{~m}, 2 \mathrm{H}, \mathrm{CH}_{2}\right), 3.56-3.63\left(\mathrm{~m}, 2 \mathrm{H}, \mathrm{CH}_{2}\right), 4.31(\mathrm{~s}, 2 \mathrm{H}$, $\left.\mathrm{CH}_{2}\right), 7.40-7.48(\mathrm{~m}, 10 \mathrm{H}, \mathrm{Ar})$.

5.1.9.2. 2-(3-(4-Aminobutyl)-2,5-dioxo-4,4-diphenylimidazolidin-1yl)acetic acid hydrochloride (27). White solid, yield 91\%; Anal. Calcd. for $\mathrm{C}_{21} \mathrm{H}_{24} \mathrm{ClN}_{3} \mathrm{O}_{4}$ : C, 60.36; H, 5.79; N, 10.06. Found: C, 60.03;
$\mathrm{H}, 5.76$; N, 10.35. ${ }^{1} \mathrm{H}$ NMR (200 MHz, DMSO): $\delta 0.78$ (t def., $2 \mathrm{H}, \mathrm{CH}_{2}$ ), 1.21 (t def., $2 \mathrm{H}, \mathrm{CH}_{2}$ ), 3.30 (t def., $2 \mathrm{H}, \mathrm{CH}_{2}$ ), 4.19 (s, $2 \mathrm{H}, \mathrm{CH}_{2}$ ), 7.18-7.44 (m, 10H, Ar).

5.1.9.3. 2-(3-(6-Aminohexyl)-2,5-dioxo-4,4-diphenylimidazolidin-1yl)acetic acid hydrochloride (28). White solid, yield 41\%; Anal. Calcd. for $\mathrm{C}_{23} \mathrm{H}_{28} \mathrm{ClN}_{3} \mathrm{O}_{4}$ : C, 61.95; $\mathrm{H}, 6.33 ; \mathrm{N}, 9.42$. Found: C, 61.58; $\mathrm{H}, 6.18$; N, 9.72. ${ }^{1} \mathrm{H}$ NMR (200 MHz, DMSO): $\delta 0.72$ (br. s, $2 \mathrm{H}, \mathrm{CH}_{2}$ ), 0.91 (br. s, $4 \mathrm{H}, \mathrm{CH}_{2}$ ), $1.20-1.33$ (m, $2 \mathrm{H}, \mathrm{CH}_{2}$ ), 2.58 (br. s, $2 \mathrm{H}, \mathrm{CH}_{2}$ ), 3.26 (t def., $\left.2 \mathrm{H}, \mathrm{CH}_{2}\right), 4.19\left(\mathrm{~s}, 2 \mathrm{H}, \mathrm{CH}_{2}\right), 7.26-7.43(\mathrm{~m}, 1 \mathrm{OH}, \mathrm{Ar}) .{ }^{13} \mathrm{C}$ NMR (200 MHz, CDCl3) $\delta$ [ppm]: 24.2, 24.8, 38.7, 39.4, 40.8, 75.2, $128.6,128.3,128.9,136.9,155.7,169.0173 .8$.

\subsection{Microbiological assays}

To determine minimal inhibitory concentrations (MICs), approximately $10^{6}$ cells were inoculated into $1 \mathrm{~mL}$ of Mueller-Hinton broth containing two fold serial dilutions of nalidixic acid. Results were read after $18 \mathrm{~h}$ at $37{ }^{\circ} \mathrm{C}$. To study synergistic activity, different fixed sub-inhibitory concentrations of the potential inhibitors, determined without antibiotic, were added during incubation with nalidixic acid. In addition, the reference efflux pump inhibitor, PA $\beta \mathrm{N}$, was used at $0.050 \mathrm{mM}$. Control experiments were carried out without the different inhibitors.

\section{Acknowledgments}

Partly supported by grants: 501/N-COST/2009/0 (K/PMN/ 000031), COST action BM0701 and Polonium 8127/2010.

\section{References}

[1] M.E. Falagas, I.A. Bliziotis, Int. J. Antimicrob. Agents 29 (2007) 630-636.

[2] I. Chopra, C. Schofield, M. Everett, A. O'Neill, K. Miller, M. Wilcox, J.M. Frère, M. Dawson, L. Czaplewski, U. Urleb, P. Courvalin, Lancet Infect. Dis. 8 (2008) 133-139.

[3] X.Z. Li, H. Nikaido, Drugs 69 (2009) 1555-1623.

[4] A. Davin-Regli, J.-M. Bolla, C.E. James, J.-P. Lavigne, J. Chevalier, E. Garnotel, A. Molitor, J.-M. Pagès, Curr. Drug Targets 9 (2008) 750-759.

[5] L.J. Piddock, Clin. Microbiol. Rev. 19 (2006) 382-402.

[6] K. Poole, Ann. Med. 39 (2007) 162-176.

[7] J.-M. Pagès, L. Amaral, Biochem. Biophys. Acta 1794 (2009) 826-833.

[8] A.I. Hidron, J.R. Edwards, J. Patel, T.C. Horan, D.M. Sievert, D.A. Pollock, S.K. Fridkin, Infect. Control Hosp. Epidemiol. 29 (2008) 996-1011.

[9] R.P. Vonberg, A. Wolter, A. Kola, S. Ziesing, P. Gastmeier, J. Hosp. Infect. 65 (2007) 372-374.

[10] M.A. Seeger, K. Diederich, T. Eicher, L. Brandstätter, A. Schiefner, F. Verrey K.M. Pos, Curr. Drug Targets 9 (2008) 729-749.

[11] Z. Pietras, V.N. Bavro, N. Furnham, M. Pellegrini-Calace, E.J. Milner-White B.F. Luisi, Curr. Drug Targets 9 (2008) 719-728.

[12] J.M. Pagès, S. Alibert-Franco, A. Mahamoud, J.M. Bolla, A. Davin-Regli, J. Chevalier, E. Garnotel, Curr. Top. Med. Chem. 8 (2010) 1848-1857.

[13] J. Handzlik, D. Maciąg, M. Kubacka, S. Mogilski, B. Filipek, K. Stadnicka, K. KiećKononowicz, Bioorg. Med. Chem. 16 (2008) 5982-5998.

[14] J. Handzlik, H.H. Pertz, T. Görnemann, S. Jähnichen, K. Kieć-Kononowicz Bioorg. Med. Chem. Lett. 20 (2010) 6152-6156.

[15] J. Handzlik, E. Szymańska, K. Nędza, M. Kubacka, A. Siwek, S. Mogilski J. Handzlik, B. Filipek, K. Kieć-Kononowicz, Bioorg. Med. Chem. 19 (2011) 1349-1360.

[16] T. Dyląg, M. Zygmunt, D. Maciąg, J. Handzlik, M. Bednarski, B. Filipek, K. KiećKononowicz, Eur. J. Med. Chem. 39 (2004) 1013-1027.

[17] K. Kieć-Kononowicz, K. Stadnicka, A. Mitka, E. Pękala, B. Filipek, J. Sapa M. Zygmunt, Eur. J. Med. Chem. 38 (2003) 555-566.

[18] K. Kieć-Kononowicz, H. Byrtus, A. Zejc, B. Filipek, P. Chevallet, Farmaco 50 (1995) 355-360.

[19] E. Pękala, K. Stadnicka, A. Broda, M. Zygmunt, B. Filipek, K. Kieć-Kononowicz Eur. J. Med. Chem. 40 (2005) 259-269.

[20] E. Szymańska, K. Kieć-Kononowicz, Farmaco 57 (2002) 355-362.

[21] E. Szymańska, K. Kieć-Kononowicz, A. Białecka, A. Kasprowicz, Farmaco 57 (2002) 39-44.

[22] J.C. Sheehan, V.A. Bolhofer, J. Am. Chem. Soc. 72 (1950) 2786-2788.

[23] J. Chevalier, A. Mahamoud, M. Baitiche, E. Adam, M. Viveiros, A. Smarandache, A. Militaru, M.L. Pascu, L. Amaral, J.-M. Pagès, Int. J. Antimicrob. Agents 36 (2010) 164-168. 